\title{
FRANCIE JAKO LAICKÝ STÁT, VÝVOJ A AKTUÁLNÍ STAV
}

\author{
PETR KAROLA
}

Abstract: $\quad$ France as a Laic State, Its Development and the Current State

This article is part of my dissertation on The Czech Republic as a Secular State. Its purpose is to explain what a secular state is, how it originated, how it has developed, and how it can be defined. Since the model of the laic state was primarily created in the gradually developing process of secularization in France and is linked to the local constitutional principle of laïcité, the article focuses primarily on this country.

The article is divided into three interrelated parts. The first part discusses the constitutional principle of laïcité, unique to France, and its development up to 1958; the second part examines the process of the separation of the state from the church and the process of the formation of the secular state, taking into account the legal and constitutional aspects of this process; and the third, the most extensive part, examines the development of both legal secularism and laïcité from 1958 to the present. Moreover, it puts the whole development in the context of the state's, gradually escalating, reaction to the growing influence of the "new" religions, especially Islam.

Keywords: France; laic state; laïcité; Islam; relationship between church and state

Klíčová slova: Francie; laický stát; lä̈cité; islám; vztah státu s církvemi

DOI: $10.14712 / 23366478.2021 .26$

\section{ÚVOD}

Tento článek je součástí disertační práce na téma Česká republika jako laický stát. Jeho účelem je vysvětlit, co to laický stát je, jak vznikl, jak se vyvíjel a jak jej lze definovat. Vzhledem k tomu, že vzorový model laického státu vznikal především v postupně se rozvíjejícím procesu sekularizace ve Francii a je spojen s místním ústavním principem laïcité, zaměřuje se článek primárně na tuto zemi.

Sekularizace je proces, kdy náboženství a jeho instituce ztrácí ve společnosti své postavení a svoji důležitost. Dochází při ní i ke ztrátě politického vlivu náboženských společností. Ve své nejobecnější podobě se jedná o odluku státu od církve a církve od státu. Pojem v sobě zahrnuje přechod od náboženské kontroly společnosti ke kontrole světské. Zvláštní, specifickou, silnou formou sekularismu je právě francouzský laický stát. 
Jejím opakem je v postmoderním světě tzv. desekularizace. Pojem byl prèdstaven na konci minulého tisíciletí americkým sociologem Peterem Bergerem. Ve své eseji Berger polemizuje s tvrzením klasických teoretiků sekularizace, kteří více než dvě staletí tvrdili, že náboženství musí v moderním světě nevyhnutelně upadat. Spolu s dalšími autory demonstruje pravý opak, např. evangelicko-protestantský vzestup v západním světě, katolictví v Latinské Americe a Africe, sílu ortodoxního judaismu či vzestup politického islámu. Podle Bergera je tedy opak pravdou a platí, že dnes je většina světa minimálně stejně nábožensky cítící jako kdykoli předtím. Jednoznačně zpochybňuje i pozici, že moderní svět je čím dál sekulárnější. Místo toho je přesvědčený, že rychlá modernizace společnosti paradoxně náboženství spíše posiluje. Berger desekularizaci označuje jako proces kontra-sekularizace. Desekularizace má odrážet přítomnost sekularizujících trendů a sil v dané společnosti/státě a vyvijí se jako prŕmá reakce na ně. ${ }^{1}$

Článek je rozdělen do tří částí. První rozebírá jedinečný ústavní princip laïcité a jeho vývoj do roku 1958, druhá se věnuje tomu, jak ve Francii probíhala odluka státu od církve a proces formování laického státu, s přihlédnutím k právním a ústavním aspektům procesu, a třetí, nejrozsáhlejší část se věnuje vývoji právního sekularismu i laïcité po roce 1958 až doposud, navíc i v souvislostech s postupně se stupňující reakcí státu na sílící vliv „nových“ náboženství, zejména islámu. Dále si rozebereme snahy určité části francouzské společnosti o desekularizaci a zastavíme se u některých palčivých problémů, které v současnosti koexistence různých náboženských komunit vyvolává. Závěry uvedené $\mathrm{v}$ tomto článku pak $\mathrm{v}$ rámci disertační práce slouží jako základní východisko k širším úvahám autora o povaze sekularismu a odluky v různých historických epochách existence „českého“ státu i v soudobé České republice.

\section{LAÏCITÉ}

Jedná se o komplexní pojem, který je specifický zvláště pro Francii. Pojem patř́ $\mathrm{k}$ obecným principům francouzského práva a obsahuje $\mathrm{v}$ sobě několik rovin: politický systém obhajující oddělení církví a státu, sekulární povahu státu a myšlenku, že co je světské, je nezávislé na jakémkoli náboženském vyznání. Jde tak o francouzské pojetí silného sekularismu, zlaicizování či zesvětštění společnosti. ${ }^{2}$

V češtině k pojmu laïcité neexistuje dostatečně přiléhavý ekvivalent. Nejblíže k němu má pravděpodobně slovo „nekonfesnost“, ale i tak je lepší pojem nepřekládat a používat jej raději v jeho plném francouzském významu. Pro správný výklad je nutné pochopit jeho historický vývoj, ale také jeho výklad ze strany francouzské Ústavní rady (Le Conseil Constitutionel), popř. Státní rady (Le Conseil d'État).

Princip laïcité se vyvíjel nepřetržitě několik století. Diskuse o jeho výkladu pokračuje i dnes, kdy je pod tlakem měnícího se postoje francouzské společnosti k islámu

1 BERGER, L. P. The Desecularization of the World: a Global Overview. In: BERGER, L. P. (ed.). The Desecularization of the World: Resurgent Religion and World Politics. Grand Rapids: William B. Eerdmans Publishing Company, 1999, s. 7-11.

2 BAUBÉROT, J. Histoire de la laïcité en France. 6e éd. [Paris]: Presses universitaires de France, [2013], s. 3-4. 
a muslimům obecně (viz kapitolu 3). Navíc, tento princip má mnoho svých výkladových variant. Některé mají své základy až v revolučním myšlení Velké francouzské revoluce a jejich popularita trvá dodnes, jiné již byly dávno překonány. Rozlišujeme tedy laïcité antireligieuse, vycházející přímo z revolučního protináboženského étosu, která prosazuje př́mé státní intervence do náboženských záležitostí a nastolení protináboženské agendy ve společnosti. Dále máme laïcité gallicane, vycházející z církevně-politického hnutí francouzského duchovenstva a politiky francouzských králů, kteří byli propojeni s katolickou církví, zároveň se však snažili vytvořit svoji vlastní církev nezávislou na Římu. Další typ prosazuje princip oddělení v doslovném slova smyslu - laïcité séparatiste. Tento proud vydáním zákona o odluce církve od státu z roku 1905 ve francouzské společnosti v podstatě zvítězil a dodnes je většinový (viz kapitolu 2). V dnešní době dochází dokonce k tvorbě proudů nových, jako je např. laïcité identitaire či laïcité anti-immigrés, které jsou spojené s problematickou integrací obyvatelstva přicházejícího z kulturně odlišných prostředí. Tento proud rozlišuje mezi náboženstvími tradičně se vyskytujícími na území Francie, které preferuje, a náboženstvími vnesenými migranty do Francie přicházejícími. ${ }^{3}$

Francouzský historik a sociolog náboženství Jean Baubérot označuje pronikání fenoménu laïcité do francouzské společnosti jako ,, seuils de la laïcité“, tedy jakési etapy, resp. stupně „laicizace“. První etapu představují léta 1789 až 1808, tj. období Velké francouzské revoluce, přijetí Deklarace práv člověka a občana, následná První francouzská odluka a přijetí zákona, stanovujícího povinnost pro každého, kdo by si chtěl otevřít veřejnou vzdělávací instituci, absolvovat jeden z oborů na l'Université de France. ${ }^{4}$ Druhý stupeň vývoje charakterizuje období, které řada francouzských autorů popisuje jako „konflikt Dvou Francii““ (,Le Conflit de Deux France“). Jedním z hlavních bojišt', kde se znesvářené strany střetávaly, byla oblast vzdělávání a školství obecně. Do tohoto období zahrnujeme přijetí zákona Julese Ferryho (1882) o laické výuce a výchově ve školách a následně i zákon Reného Gobleta, který posunul hranici z roku 1882 tak, že pověřil výukou na veřejných školách výhradně sekulární zaměstnance. Tato etapa končí roku 1905 přijetím zákona o tzv. Druhé francouzské odluce. Ten je považován za klíčový milník, co se týká právního vymezení tohoto principu. ${ }^{5}$ Dodnes tvoří materiální součást „ústavního řádu“, i když se formálně nejedná o zákon ústavní síly. Pro další etapu vývoje je signifikantní postupná konstitucionalizace principu laïcité v rámci republikových ústav, zejména čtvrté ${ }^{6}$ a páté francouzské republiky. ${ }^{7,8} \mathrm{Zde}$ je namístě upozornit na fakt, že ani ústava čtvrté, ani ústava páté republiky princip laïcité prímo explicitně nedefinuje, ale obě se ho dovolávají. ${ }^{9}$

\footnotetext{
Tamtéž, s. 56-71.

Tamtéž, s. 23-26.

Tamtéž, s. 3-4, 27-52; POULAT, E. Liberté, laïcité: la guerre des deux France et le principe de modernité. Paris: Cujas-Cerf, 1988, s. 73-87.

6 Čl. 1, první hlavy ústavy: „Francie je republikou nerozdélitelnou, laickou, demokratickou a sociální. “

7 Ústava páté republiky přejímá první článek ústavy z roku 1946 a dále ho rozvíjí: „Francie je republikou nerozdělitelnou, laickou, demokratickou a sociální. Zajištuje rovnost všech občanủ před zákonem bez ohledu na jejich původ, rasu či náboženství. Republika respektuje veškerá vyznání. "

8 BAUBÉROT, Histoire de la laïcité en France, s. 105-107.

9 Čl. 13 preambule Ústavy z roku 1946, ve vztahu ke školství, a čl. 1 Ústavy z roku 1958, obecně.
} 
V širším smyslu tento pojem vyjadřuje princip, kdy všechny dílčí stavební kameny společnosti (politika, školství, kultura atd.) musí být ve vztahu ke státem uznaným náboženstvím neutrální. V užším smyslu pod tímto pojmem rozumíme odluku církví od státu. Stát má být naprosto nezávislý na jakékoliv církvi, a naopak církve jsou nezávislé ve vztahu ke státu. ${ }^{10}$

Jak lze odvodit z výše uvedené textace, jedná se především o princip obecný. Jeho myšlenkový a právní zdroj můžeme vysledovat až k čl. 10 Deklarace práv člověka a občana. „Nikomu se nesmí dít újma pro jeho názory i náboženské, ledaže by jejich projev rušil porádek stanovený zákonem. "11 Dále musí být zmíněn zákon o odluce církve od státu (1905), který definuje základní pravidla principu laïcité přesto, že není explicitně zmíněn ani na jediném místě tohoto zákona. Jedná se o svobodu svědomí, úplné oddělení církví od státu a svobodu vyznání. Laïcité tedy zaručuje svobodu svědomí jako forum internum. Z ní pak vyplývá právo svobodně projevovat víru nebo přesvědčení jako forum externum, avšak výhradně v mezích úcty k veřejnému pořádku (viz kapitolu č. 3). Laïcité znamená rovněž i státní neutralitu. Garantuje rovnost všech před zákonem bez rozdílu v náboženství a víre i rovnost samotných náboženství a církví mezi sebou, včetně ateismu. A co je klíčové, zajištuje také právo „nevěřit“, tj. nemít náboženství, měnit ho nebo se ho beztrestně zř́ici. Zaručuje svobodný výkon kultu a svobodu náboženského vyznání. Nikdo nesmí být nucen respektovat dogmata nebo náboženské předpisy. ${ }^{12}$ To je mimořádně aktuální a zároveň kontroverzní princip, který prakticky denně naráží na diametrálně odlišný postoj významné části francouzské muslimské náboženské obce. Přesněji, ta jej čím dále otevřeněji odmítá (viz kapitolu č. 3). Neutrální stát, který se řídí principem laïcité, sice toleruje náboženství a kulty, zároveň však nutí církve, aby se mu v některých otázkách podřídily. Jedním z cílů tohoto principu je logicky zajistit, aby žádné náboženství nemohlo stát ovládnout, ${ }^{13}$ a uhlídat, že nebudou porušována stanovená pravidla, vymezující prostor pro volnou soutěž jednotlivých náboženství. ${ }^{14}$

Laïcité ovlivňuje jak veřejnou sféru, tak i tu neveřejnou (v rámci soukromoprávních vztahů). Pokud se zde chtějí subjekty bez problémů pohybovat, musí tak činit bez odkazu na své vyznání, a to pod hrozbou zásahu státu. ${ }^{15}$ Tato neutralita představuje liberální princip, který zahrnuje dva typy závazků státu. Prvním závazkem je, že stát musí respektovat právo každého člověka vybrat si svobodně pravdu, která bude ř́́dit jeho život. Proto se stát zříká propagace jakékoliv konkrétní víry. Z toho logicky vyplývá druhý závazek, tj. pokud neutralita státu zakazuje jakýkoliv tlak na jednotlivce $\mathrm{v}$ rámci jeho volby víry či svědomí, musí stát respektovat zároveň i svobodu jeho volby. ${ }^{16}$

10 BARBIER, M. Esquisse d'une théorie de la laïcité. Le débat. 1993, vol. 5, n 77, s. 65.

11 „, Nul ne doit être inquiété pour ses opinions, même religieuses, pourvu que leur manifestation ne trouble pas l'ordre public établi par la Loi. “

12 RENAN, E. Qu'est-ce qu'une nation? [1882]. Whitefish: Kessinger Publishing, 2010, s. 36.

13 KINTZLER, C. Qu'est-ce que la laïcité? Paris: Librairie Philosophique Vrin, 2007, s. 22.

14 BOKDAM-TOGNETTI, É. Le financement des cultes dans la jurisprudence du Conseil d'État. Les Nouveaux Cahiers du Conseil constitutionnel. 2016, vol. 4, n 53 , s. 33.

15 Tamtéž, s. 6.

16 RIVERO, J. La notion juridique de laïcité. Recueil Dalloz. 1949, n 33, s. 137-138. 
Francouzský právní sekularismus se, v souvislosti s principem laïcité, vyvíjel souběžně jak se sociálními změnami, tak ruku v ruce i se vznikem nových společenských hodnot, jako jsou pluralismus a tolerance. Tento vývoj probíhá bouřlivě i dnes. ${ }^{17}$

\section{FRANCOUZSKÁ ODLUKA - VÝVOJ LAICKÉHO STÁTU}

\subsection{PRVNÍ ODLUKA 1789-1802}

Jak bylo popsáno výše, výchozím bodem postupné sekularizace, resp. laicizace francouzské společnosti je Velká francouzská revoluce. ${ }^{18}$ Tato odluka nebyla sice ve výsledku trvalá, ale prakticky až do roku 1905 byla centrálním tématem konfliktu mezi představiteli monarchistické konzervativní katolické Francie a zastánci sekulární republikánské Francie (,konflikt Dvou Francií“). V kontextu problémů s integrací osob z kulturně a nábožensky odlišných prostředí, migrujících do Francie, je aktuální i dnes.

V rámci monarchie bylo fungování státu a jeho aparátu s (katolickou) církví pevně provázáno. Duchovenstvo reprezentovalo jeden ze tří hlavních mocenských piliřů a disponovalo i velkou ekonomickou mocí. ${ }^{19}$

Po vyhlášení Ústavodárného národního shromáždění (dále jen „Shromážděni““) a následném dobytí Bastily vydalo Shromáždění dne 26. srpna 1789 Deklaraci práv člověka a občana. ${ }^{20}$ Její čl. 3 deklaruje, že: , Jediným zdrojem veškeré suverenity je Národ. Žádná instituce, žádný jednotlivec nemůže vykonávat pravomoc, která by od něj výslovně nepocházela. " $21 \mathrm{~V}$ podstatě tím stvrzuje, že státní suverenita a s ní spojená moc/vláda nepochází od Boha, ale od národa/lidu. Neguje tím církevní suverenitu i povinnost vládce reprezentovat církev zastupující Boha. Ruší i jeho povinnost být při svém nástupu na trůn pomazán a posvěcen. Tato vnitřní neutralita veřejné moci je základním výchozím předpokladem jakékoliv odluky. Jedná se o první dokument, který ve svém čl. 10 již prrímo hovoří o sekularizaci francouzské společnosti, resp. o náboženské svobodě. ${ }^{22}$ Avšak zde popsaná náboženská svoboda se vztahovala výhradně na katolíky a protestanty. K jejímu rozš́írení na judaismus došlo až v roce $1791 .{ }^{23}$

Základní problém, který muselo Shromáždění řešit, byl nedostatek peněz a obrovské dluhy převzaté od Bourbonů. K naplnění pokladny tak posloužila konfiskace církevního majetku, který byl prohlášen za majetek národní, a to prostřednictvím znárodňovacího zákona ze dne 14. dubna $1790 .{ }^{24}$

17 CHELINI-PONT, B. Legal Secularism in France Today: between Two Paths. In: CONTRERAS, J. - MARIA DE CODES, R. (eds.). Trends of Secularism in a Pluralistic World. Madrid: Iberoamericana Vervuert, 2013, s. 1.

18 BAUBÉROT, Histoire de la laïcité en France, s. 23-26.

19 Tamtéž, s. 5-6.

20 MAUROIS, A. - DROZD, M. - BOROVIČKOVÁ, A. Dějiny Francie. Praha: Nakladatelství Lidové noviny, 1994, s. 235-242.

21 Déclaration des Droits de l'Homme et du Citoyen de 1789. In: République Française: Liberté, Egalité, Fraternité: Légifrance [online]. [cit. 2017-01-06]. Dostupné na: https://www.legifrance.gouv.fr/contenu /menu/droit-national-en-vigueur/constitution/declaration-des-droits-de-l-homme-et-du-citoyen-de-1789.

22 Tamtéž.

23 BAUBÉROT, Histoire de la laïcité en France, s. 9.

24 TINKOVÁ, D. Francouzská revoluce. Praha: Triton, 2008, s. 84. 
V únoru 1790 bylo zakázáno skládání řeholních slibů a byly rozpuštěny všechny řády a kongregace. Jen kláštery poskytující školní výuku a sociální služby mohly dále vykonávat svoji činnost. Řeholníkům, kteří opustili kláštery, měla být zajištěna doživotní renta. ${ }^{25}$ V červenci 1790 vyhlásilo Ústavodárné národní shromáždění tzv. civilní konstituci kléru (Constitution civile de clergé). V rámci ní došlo k přijetí mechanismu, podle kterého měli být faráři a biskupové voleni obyvatelstvem, resp. biskupové faráři a děkany a ti obyvatelstvem s trvalým pobytem $v$ príślušném regionu. A to prostřednictvím nerovného volebního práva podle výše odvedené daně. Volební právo bylo přiznáno i ateistům, protestantům, dokonce i př́slušníkům jiných náboženství. ${ }^{26} \mathrm{~V}$ listopadu 1790 došlo k přijetí dekretu, který stanovil povinnost duchovních složit př́isahu věrnosti státu. Pokud byla př́saha odmítnuta, znamenalo to rezignaci na duchovní úřad a ona osoba přestala mít nárok na vyplácení platu od státu. Duchovní, kteří nepř́ísahali věrnost, nemohli, pod hrozbou sankce, vykonávat žádné veřejné obřady. ${ }^{27} \mathrm{Na}$ podzim roku 1791 byla Shromážděním vyhlášena první psaná ústava. Ta mimo jiné garantovala náboženskou svobodu inkorporací článků Deklarace práv člověka a občana. ${ }^{28}$

V listopadu 1791 byl vydán dekret, na základě kterého byli duchovní, co nesložili přísahu věrnosti státu, prohlášeni za osoby podežrelé a postaveni pod př́mý státní dozor. Revoluce eskalovala a situace se vyhrotila již v roce 1792, kdy došlo k pádu monarchie a vyhlášení republiky. Dalším postupným krokem na cestě $\mathrm{k}$ úplné sekularizaci bylo roku 1792 přijetí zákona, který legislativně zakotvil civilní sňatek - na uzavírání sňatků měla do té doby monopol církev. ${ }^{29}$

V témže roce došlo i k zákazu konání katolických bohoslužeb. Situace postupně gradovala. ${ }^{30} \mathrm{~V}$ dubnu došlo $\mathrm{k}$ zákazu nosit duchovenský oděv a všechna náboženská bratrstva a náboženská sdružení byla zakázána. V srpnu 1792 byl vydán dekret, na jehož základě byli duchovní internováni a následně deportováni (nejčastěji do zámořských kolonií). V srpnu došlo ke zrušení všech ženských klášterů a ke konfiskaci jejich majetku. ${ }^{31}$

V červnu 1793 se moci chopili jakobíni, radikální kř́ídlo republikánů. Okamžitě nastolili vládu teroru, tzv. jakobínskou diktaturu. Jakobíni zavedli Kult rozumu, který museli všichni přijmout jako náhražku za náboženství. ${ }^{32} \mathrm{~V}$ říjnu 1793 byl na ulicích Paříže zakázán jakýkoliv prodej náboženských symbolů a v listopadu téhož roku došlo k uzavření všech kostelů v Paříži. V říjnu byl zrušen kalendáŕ a byl přijat nový, ryze revoluční, který odstranil neděli jako jeden ze symbolů náboženství. ${ }^{33}$

Po stětí Robespierra řada těchto náhražek náboženské symboliky skončila, nicméně základní prvky, které se vyvinuly v rámci revolučního procesu, přetrvaly. Křest’anské vyznání víry nahradilo Prohlášení lidských práv. Ústava nového státu nahradila církevní právo. Trikolóra nahradila symbol kř́že, institut církevních sňatků a pohřbů nahradily

25 NOWAK, J. R. Církev a Velká francouzská revoluce. Olomouc: Matice cyrilometodějská, 2003, s. 35-38.

26 Tamtéž, s. 38-40.

27 Tamtéž, s. 42.

28 MALÝ, R. Cirkevni dějiny. Olomouc: Matice cyrilometodějská, 2001, s. 232

29 BAUBÉROT, Histoire de la laïcité en France, s. 12.

30 Tamtéž, s. 45.

31 PELCZAR, J. S. Rewolucja francuska wobec religii katolickiej i jej duchowieństwa. Przemyśl: Drukarni Jana Lazora w Przemyślu, 1922, s. 22.

32 MALÝ, c. d., s. 233.

33 NOWAK, c. d., s. 68-69, 71. 
příslušné státní registry. Učitelé laici nahradili ve školách kněze. Oltář a mešní obět' nahradil „oltář vlasti“. Města, ulice a další místa změnila své názvy vycházející z náboženských zdrojů. Uctívání svatých bylo nahrazeno uctíváním mučedníků revoluce. Křest'anskou etiku nahradila etika občanských ctností a sociální harmonie, vycházející z myšlenek osvícenců. ${ }^{34}$

Po jakobínské diktatuře nastává pětileté období vlády Direktoria, které sice povolilo katolický kult, ale obnovu církevní organizace ne. ${ }^{35}$ Během roku 1796 a v první polovině roku 1797 došlo ke krátkodobému uvolnění situace, kdy byly postupně rušeny dekrety nepřátelské vůči katolické církvi. Avšak v záŕí roku 1797 došlo k prrijetí nového dekretu, který stanovil povinnost duchovních prrísahat nenávist k monarchii. ${ }^{36}$ Téhož roku Direktoriát prohlásil katolický kult znovu za zakázaný. Ústup od sekularizace a obnovu církevního života přinesla až doba vlády Napoleona. Ten se nejdříve zúčastnil státního převratu (1799), ale po krátké epizodě 1. konzula se v roce 1800 prohlásil za císaře. Jako císař obnovil církevní organizaci v plném rozsahu s výjimkou řeholních rrádů. Ale $\mathrm{v}$ rámci probíhajícího konfliktu s papežem Piem VII. vyhlásil v roce 1802 znovu účinnost tzv. galikánských článků ve formě tzv. organických článků stanovujících nezávislost francouzské církve na papeži. Prakticky došlo k jejímu plnému podřízení panovníkovi Francie. ${ }^{37}$

Celkem 77 právních nařízení doplňovalo konkordát, uzavřený mezi Francií a Svatým stolcem v roce 1801. Konkordát a na něj navázaná legislativa zavedla ve Francii tzv. systém uznávaných kultů. Ten akceptoval výhradně tzv. uznávaná vyznání (tzv. cultes reconnus). ${ }^{38}$ Katolická víra byla prohlášena za náboženství většiny francouzského obyvatelstva. Stejně jako další uznaná vyznání a kulty nesměla být státním náboženstvím a musela se podř́dit státu. ${ }^{39} \mathrm{~V}$ praxi však došlo $\mathrm{k}$ obnovení úzké vazby státu a církve, když např. zaměstnání biskupů, a to včetně jejich platů, bylo pod kontrolou státu.

Celé 19. století se ve Francii nese v duchu již výše zmíněného mocenského souboje mezi zástupci „Dvou Francií“. Bitva se vedla zejména o sekularismus na veřejných školách a o výuku náboženství. Konflikt přetrval až do roku 1905.

\subsection{DRUHÁ ODLUKA}

Druhá francouzská odluka byla provedena zákonem, který byl schválen poslaneckou sněmovnou Francie dne 9. prosince $1905^{40}$ (dále jen „odlukový zákon $\left.1905^{“ `}\right)$. Zákon se stal součástí ústavy třetí francouzské republiky a přes mnohé novelizace platí ve Francii dodnes. Je považován za materiální součást ústavního řádu (celý ne - viz kapitolu 3). V původním znění obsahoval 44 článků, rozdělených do 6 hlav. ${ }^{41}$

\footnotetext{
${ }^{4}$ KÜNG, H. Malé dějiny katolické cirkve. 2. vyd. Brno: Barrister \& Principal, 2010, s. 105-106.

5 MALÝ, c. d., s. 234.

${ }^{6}$ NOWAK, c. d., s. 82-83.

MALÝ, c. d., s. 235-236.

38 Patřilo sem většinové vyznání katolické, protestantské a v roce 1808 byla uznána i víra židovská.

39 BAUBÉROT, Histoire de la laïcité en France, s. 19-21.

40 Loi du 9 décembre 1905 concernant la séparation des Eglises et de l'Etat. In: Les collections du Musée des Archives nationales [online]. [cit. 2017-01-06]. Dostupné na: http://www.culture.gouv.fr/Wave/image /archim/Pages/04816.htm.

41 Tamtéž.
} 
Byl přijat s cílem ukončit souboj „Dvou Francii““. Z důvodu silného odporu Vatikánu byl později doplněn o řadu prováděcích zákonů. Režim nastolený účinností tohoto zákona vycházel z premisy, že třetí republika nadále neuznává, nefinancuje a ani jinak nepodporuje žádné konkrétní vyznání. ${ }^{42}$

Zákon nahradil výše vymezený režim tzv. uznaných vyznání. Stojí na dvou základních piliřích: na svobodě vyznání, omezené pouze veřejným pořádkem (ordre public), podle čl. $1,{ }^{43}$ a zásadě odluky státu a církve, deklarované v čl. 2. ${ }^{44}$ Odluka vyloučila podporu státu a samosprávy jakémukoliv kultu a hledisko kultovní bylo odstraněno i ze státního zákonodárství. Důsledkem bylo to, že legislativa upravující postavení církví a náboženských společností s nimi nebyla předem konzultována. Navíc zákonodárce přestal promítat náboženské hledisko i do nesouvisející legislativy. Odluka vedla k zásadním zásahům i do rodinného a správního práva. Matriky byly civilní a manželství obligatorně taktéž. Výuka náboženství na státních školách byla nahrazena výukou morálky a náboženství se nadále mohlo vyučovat jen na školách soukromých. Zrušení podpory státu vedlo k zastavení proplácení výdajů spojených s náboženskými aktivitami. ${ }^{45}$ Nová zákonná úprava požadovala zavést pro všechny církve, resp. jejich organizace, rovnost podmínek, a to především v oblasti veřejného výkonu kultu. Soukromý projev víry zůstal vnitřní záležitostí každého jednotlivého občana a státem omezován nebyl. Z toho důvodu zavedl stát jednotnou soukromoprávní sdružovací formu, tzv. sdružení kultová (associations cultuelles). Zákon se jim snažil vnutit jednotnou strukturu, to se však nakonec zcela nepodařilo. Úprava byla postavena tak, aby kultová sdružení svým okruhem působnosti př́mo kopírovala církevní okrsky. Inspirací se stala civilní konstituce kléru z revolučního roku 1790. Nově úprava kultovým sdružením nepřiznala veřejnoprávní charakter. Všechny církevní právnické osoby, které neodpovídaly nové formě sdružení a nespadaly pod výjimku dle čl. 3 odlukového zákona 1905, byly v souladu s čl. 2 odst. 2 zrušeny. Díky tomu, že Papež Pius X. encyklikami z 11. února 1906 a 10. srpna 1906 zakázal vytvářet nová kultová sdružení, katolická církev přišla i o majetek, o který přijít vůbec nemusela. Jmění původních církevních právnických osob mělo být totiž novým sdružením předáno v jednoleté prekluzivní lhůtě (čl. 4 a 19 odlukového zákona 1905). Tento majetek tak propadl státu a obcím. Korunu všemu pak nasadily soudy, které ve své judikatuře neuznávaly kněží, kteří se i přes odpor papeže rozhodli kultová sdružení založit, s tím, že když odmítají rozhodnutí Svatého stolce, nejsou ,, ve spojení s církví katolickou “. ${ }^{6}$

Zákon počítal se spojováním nižších místních sdružení do vyšších asociací, např. celostátních. Obvod působnosti, ve kterém sdružení vykonávalo své pravomoci, však nesměl přesahovat velikost církevního okrsku. U člena sdružení nebylo požadováno francouzské občanství. Stát přestal platit duchovenstvo i zaměstnance církví. Veškeré církevní finanční zdroje musely nadále pocházet pouze ze soukromých zdrojů. Dle čl. 5 a čl. 12 (nemovitosti) odlukového zákona 1905 měl být veškerý majetek, který církve

42 MAYEUR, J.-M. La séparation des Eglises et de l'Etat. Paris: De l'Atelier, reed. 1991, s. 169-173.

43 „Republika zajištuje svobodu svédomí. Zaručuje svobodu vyznání v souladu s omezeními přijatými dále v zájmu veřejného pořádku. “

44 „Republika neuznává, neplatí ani nepodporuje žádné náboženství. “

45 BAUBÉROT, Histoire de la lä̈cité en France, s. 209.

46 HÁCHA, E. - HOETZEL, J. - WEYR, F. - LAŠTOVKA, K. Slovník veřejného práva československého. Sv. III, [P-R]. Repr. pův. vyd. z r. 1934. Praha: Eurolex Bohemia, 2000, s. 826. 
a náboženské společnosti obdržely k užívání od obcí a od státu, vrácen zpět. Čl. 6 zajišt'oval, že veškeré půjčky, které stát církvím a náboženským organizacím poskytl, musely být ihned splaceny. Na základě těchto opatření přišly náboženské společnosti a církve, především katolická, o většinu svého dosavadního velkého majetku, který přečkal i konfiskace Velké francouzské revoluce.$^{47} \mathrm{Na}$ druhou stranu, novým sdružením dal stát možnost vybírat prostředky na svůj provoz prostřednictvím stanovení členských prríspěvkủ, pořádáním sbírek a vybíráním náhrad za bohoslužebné úkony. Zároveň byl stanoven limit majetku, který nemohlo sdružení překročit a jehož dodržování bylo kontrolováno státní správou. Zákon ve svém čl. 28 ošetřoval i použivání náboženských symbolů, když konstatoval, že je zakázáno umist'ovat jakékoliv náboženské symboly na veřejných památkách.

Svatý stolec odmítl celou odlukovou koncepci i novou formu sdružování. Zlom nastal až s přijetím zákonů z ledna a března 1907, kdy byla duchovním i věrícím dána možnost svobodně svolávat shromáždění, a to bez jejich předchozího ohlášení. S tímto řešením se již Vatikán smíriil. ${ }^{48}$ Diplomatické vztahy se Svatým stolcem byly obnoveny v roce 1921 a téhož roku bylo ustanoveno právo státu na kontrolu jmenování biskupů. ${ }^{49}$ Vzhledem k tomuto opatření začaly od roku 1924 vznikat sdružení o řád vyšší, tj. na úrovni diecézí (associations diocésaines).

\section{SOUČASNÝ STAV}

Základy úpravy náboženského života v současné Francouzské republice nalezneme stále v Deklaraci práv člověka a občana, v Preambuli Ústavy z 27. září 1946 a v Ústavě republiky z roku 1958 (dále jen ,ústava“). Úprava je, vzhledem ke staleté tradici odluky státu, církví a náboženských společností, až překvapivě strohá. Nicméně, text ústavních zákonů je v tomto př́padě nutné vždy doplnit o odlukový zákon 1905, který je považován za materiální součást ústavního řádu, nikoliv však celý. To je, podle rozhodnutí z 23. listopadu 1973, č. 77-87 DC Ústavní rady, př́ípad zejména zásad svobody svědomí, svobodného výkonu kultu, principu „separace“ a zákazu financování kultu státem, ministerstvy i obcemi, které jsou stanoveny v čl. 1 a 2 odlukového zákona 1905. ${ }^{50}$ Preambule Ústavy z 27. záŕí 1946 uvádí v čl. 5, že „, [...] nikomu nesmí být $v$ zaměstnání zpuisobena újma z důvodu jeho pưvodu, názoru či vyznání.. Čll. 13 pak deklaruje povinnost státu zajistit bezplatný, laický a veřejný vzdělávací systém na všech jeho stupních. ${ }^{51}$

Ústava (1958) v čl. 1 ř́ká, že „,Francie je nedilná, laická, demokratická a sociální republika. Zaručuje rovnost před zákonem všem občanům bez rozdílu puvodu, rasy

47 Loi du 9 décembre 1905 concernant la séparation des Eglises et de l'Etat, s. 2-3, 17-18.

48 HÁCHA - HOETZEL - WEYR - LAŠTOVKA, c. d., s. 826.

49 MESSNER, F. State and Church in France. In: ROBBERS, G. (ed.). State and Church in the European Union. Baden-Baden: Nomos, 2005, s. 216.

50 Rozhodnutí Ústavní rady č. 77-87 DC z 23. listopadu 1977.

51 Préambule de la Constitution du 27 octobre 1946. In: République Française: Liberté, Egalité, Fraternité: Légifrance [online]. [cit. 2021-04-10]. Dostupné na: https://www.legifrance.gouv.fr/Droit-francais/Constitution/Preambule-de-la-Constitution-du-27-octobre-1946. [vlastní překlad autora] 
nebo náboženství. Uznává všechna vyznáni. "52 Ústavní rada, rozhodnutím z 19. listopadu 2004, č. 2004-505 DC, upřesnila, že čl. 1 ústavy zakazuje komukoli využívat své víry k překonání společných pravidel nastavených mezi skupinami tvořenými veřejností a jednotlivci. ${ }^{53}$ Náboženská svoboda je dle dalšího rozhodnutí Ústavní rady z 23 . listopadu 1977, č. 77-87 DC, ${ }^{54}$ vykládána jako úplně první zásada, a to právě skrze čl. 10 Deklarace práv člověka a občana, která sama o sobě zahrnuje to, co francouzští právníci nazývají ,ústavním blokem“ doprovázejícím ústavu. Náboženská svoboda jako svoboda názorů a přesvědčení je završena právním respektováním všech přesvědčení, jak je uvedeno v čl. 1 ústavy, a dalším ústavním principem svobody svědomí. Proto, i když jsou rozdíly mezi svobodou přesvědčení, svědomí, uctívání a náboženství jen velmi jemné, dvě poslední z nich by nebylo možné uplatnit bez ostatních. ${ }^{55} \mathrm{~V}$ roce 2009 Ústavní rada v rozhodnutí č. 2009-591 DC potvrdila ústavní hodnotu zásady laïcité. ${ }^{56}$ Jsou i další ústavně uznané a chráněné svobody, které dávají náboženské svobodě její obsah. Mezi ně patří především svoboda projevu, shromažd’ování a sdružování. ${ }^{57}$

Konsenzus na právním sekularismu nebyl od syntézy provedené pátou republikou v roce 1958 nikdy, na rozdíl např. od USA, významně zpochybněn, a to ani z katolických konzervativních kruhů (to neplatí pro zastánce jiných náboženství). Pokud je tento konsenzus napadán, děje se tak především z akademických kruhů. Proč tomu tak je? Francouzské chápání sekulárního státu a právního sekularismu vychází z přesných definic. „Sekulární stát je nekonfesní stát bez zásadního nebo konkordátního spojení s jedním nebo několika náboženstvími, jehož filozofický ideál je demokratický a republikánský a jehož hodnoty jsou liberální. "58

Ano, prakticky pořád se vede diskuse mezi levicově orientovanými francouzskými intelektuály a jejich odpůrci z opačného konce politického spektra, jestli je republika kompletně oddělená od náboženství a co tato separace vlastně představuje v každodenním životě občana. Tak např. v 50. letech 20. století byl sekularismus pojem, který používala francouzská levice k obraně veřejných škol proti konkurenci ze strany soukromých katolických škol. To odstartovalo etapu, které se ve Francii ř́ká „Válka škol“. Tato „válka“ skončila príijetím ústavy páté republiky a prohlášením Ústavní rady, že akademická svoboda, spojená se svobodou svědomí, je ústavním právem. Výměnou za státní podporu katolických školních platů se katolické diecéze ve Francii dohodly, že budou poskytovat vyučování na svých školách jako veřejnou vzdělávací službu. Připustily svobodu rodičů rozhodnout, zda své děti v rámci katolické školy zapíšou do tř́́d, kde byl vyučován katechismus. Během 70. a 80. let dvacátého století se debata o sekularismu z politických diskusí vytratila. 59

\footnotetext{
KLOKOČKA, V. - WAGNEROVÁ, E. Ústavy států Evropské unie. Praha: Linde Praha, a. s., 1997.

Rozhodnutí Ústavní rady č. 2004-505 DC z 19. listopadu 2004.

Rozhodnutí Ústavní rady č. 77-87 DC z 23. listopadu 1977.

CHELINI-PONT, Legal Secularism in France Today..., s. 2.

Rozhodnutí Ústavní rady č. 2009-591 DC z 22. ř́jna 2009.

CHELINI-PONT, Legal Secularism in France Today..., s. 2.

Tamtéž, s. 4.

59 CHELINI-PONT, B. Is Laïcité the French Civil Religion? George Washington International Law Review. 2010, CIVIL RELIGIONS, Vol. 41, No. 44, s. 774-775, 778.
} 
K jejímu oživení došlo ke konci 80. let, tj. když se na veřejných školách začínají častěji vyskytovat symboly spojené s islámem jako např. šátky nošené muslimskými studentkami. Než se pustíme do problematiky působení islámu ve Francii, je potřeba rríci, že se jedná o velmi rozsáhlé téma nejenom právní, sociální, teologické, kulturní, sociologické, ale dotýká se např. i problematiky feminismu, což by vydalo na plnohodnotnou disertaci. Proto se autor pokusí nastínit jen základní právní problémy, kterým Francouzská republika a společnost v posledních desetiletích čelí ve vazbě na rozšiřující se společenský vliv islámu, který tvoří již druhé nejpočetnějšš náboženství po křest’anství. ${ }^{60}$ Podle posledních údajů žije ve Francii přibližně mezi 5 až 6 miliony muslimů. ${ }^{61}$

Vzestup islámu ve Francii má své kořeny v politice ekonomického přistěhovalectví především ze zemí „Muslimského světa“, aplikovaného nejenom ve Francii, ale i v řadě dalších evropských zemích od 70. let 20. století. Ekonomiky těchto zemí se takto snažily čelit ekonomické krizi, ve které se ocitly. Tato politika počítala s rozšířením občanství na ekonomické přistěhovalce i jejich rodiny. Jejím cílem bylo tuto „pracovní sílu“ co nejrychleji ,integrovat“ do francouzské společnosti. Vše bylo založené na premise, že jakmile se z prristěhovalce stane občan, přijme již dobrovolně nepsanou, tichou dohodu, respektující konkrétní vzorec chování, zvláště pokud jde o náboženskou víru. Její manifestace navenek měla být zásadně diskrétní a ve veřejné sféře striktně v duchu laického státu. Tento model však začal být kritizován již v osmdesátých letech, a to díky dvěma jevům. První z nich je čistě sociální. Jde o diskriminaci, které přistěhovalci čelili ve všech aspektech každodenního života, zejména v práci (mzdy a podmínky), v př́stupu k bydlení, vzdělání, a především z hlediska sociálního respektu. Druhým fenoménem, s prvním úzce souvisejícím, byl protest proti uplatňování sekularismu ve veřejné sfére. Praktická aplikace sekularismu začala být mnohými věřícími odsuzována jako forma diskriminace, protože tlak na věrícího, aby udržel svoji víru v soukromém prostoru, ve skutečnosti u části společnosti podporoval „pohrdání“ novými náboženstvími. ${ }^{62}$ Oba tyto jevy se ve francouzské společnosti vyskytují stále ve velké míře.

Na přelomu 80. a 90. let se do společenské pozornosti dostává problematika zakrývání muslimských žen ve veřejných školách. Celonárodní debatu odstartovalo, když dne 18. zárí 1989 bylo ve francouzském Creilu pozastaveno studium tří muslimských dívek za to, že si odmítaly ve veřejné škole sundat hidžáb. ${ }^{63}$ Studentky argumentovaly tím, že ústava nošení šátků ve veřejných školách umožňuje. Tato událost vedla $\mathrm{k}$ bouřlivé polemice, zda je nošení šátku ve školách porušením principu laïcité. ${ }^{64} \mathrm{Jak}$ bylo popsáno v předchozích kapitolách, odluka na školách ve Francii byla vždy absolutním středobodem debaty o sekularizaci. Veřejné školy v principu reprezentují samotnou podstatu laïcité jako hlavního nástroje sekularizace společnosti. Tématu muslimských šátků ve

60 Observatoire de la Laïcité. Rapport des français à la religion et aux convictions: chiffres clés. In: Gouvernement: Liberté, Egalité, Fraternité [online]. 2019 [cit. 2021-04-10]. Dostupné na: https://www .gouvernement.fr/rapport-des-francais-a-la-religion-et-aux-convictions-chiffres-cles.

61 SCHWARZENBACH, A. Fighting the "Threat from Within": France and Its Counter-Radicalization Strategy. In: VIDINO, L. (ed.). De-Radicalization in the Mediterranean: Comparing Challenges and Approaches. Milano: Ledizioni-LediPublishing, 2018, s. 21.

62 CHELINI-PONT, Legal Secularism in France Today..., s. 9.

${ }_{63}$ Muslimský šátek, kterým si žena zahaluje vlasy, krk a poprsí.

${ }^{64}$ KILLIAN, C. The Other Side of the Veil: North African Women in France Respond to the Headscarf Affair. Gender \& Society. 2003, Vol. 17, No. 4, s. 567. 
veřejných školách se, pod vedením strany Le Front National, ujala především radikálně pravicová scéna, která nošení šátků ve školách zásadně odmítala právě s poukazem na sekularismus Francouzské republiky. Druhá strana debaty argumentovala ústavně chráněnou svobodou projevu. Př́ípad se objevil až před Státní radou, která 27. listopadu 1989 vydala své první rozhodnutí týkající se nošení muslimských šátků ve školách. V něm judikovala, že nošení šátku jako kvazi náboženský výraz je obecně slučitelné s dodržováním principu laïcité na veřejných školách, resp. že nošení je př́ípustné, pokud není př́liliš „ostentativní“. Určení, zdali je nošení šátku „ostentativní“ natolik, že podkopává sekularismus, ponechala Státní rada na daných školách. ${ }^{65} \mathrm{Již} \mathrm{v} \mathrm{prosinci} \mathrm{ministr}$ školství Jospin vše stvrdil prohlášením, ve kterém určil, že učitelé mají rozhodovat, zda je možné šátky ve třídách nosit na ad hoc bázi. Toto rozhodnutí se záhy ukázalo jako velmi nešt'astné, aplikačně neuchopitelné a logicky vedlo k řadě lokálních incidentů. Celý konflikt to dále akcelerovalo a obě strany sporu více radikalizovalo. ${ }^{66}$ Mezi roky 1994 až 2003 došlo cca ve 100 př́padech studentek k pozastavení nebo vyloučení ze studia na středních a vysokých školách kvůli nošení šátku ve tř́́dě. Nicméně, v téměř polovině těchto prípadů byla správní rozhodnutí francouzskými soudy zrušena na podkladě výše zmíněného rozhodnutí Stání rady. ${ }^{67} \mathrm{~K}$ uklidnění nepomohla ani instrukce vydaná v roce 1994 novým ministrem školství Bayrouem, která vymezila rozdíl mezi „diskrétními“ náboženskými symboly, které lze do učeben vnést, a „ostentativními“ náboženskými symboly (např. i hidžáb), které nosit do veřejných škol nelze.

Státní rada udržela svoji interpretaci po celá 90. léta a národní debata se uklidnila. Poté však prrišel teroristický útok ze dne 11. zář́í 2001 na Světové obchodní centrum v New Yorku. To vyvolalo obecnou nedůvěru vůči islámu v celém „západním“ světě. Celonárodní debata o muslimských symbolech ve školách se znovu rozhořela naplno. Vše vyústilo v prosinci 2003 v předložení návrhu zákona, který měl v duchu sekularismu výslovně zakazovat jakékoli viditelné nošení známek náboženské př́slušnosti na veřejných školách. Změny v právním řádu týkající se církví a náboženských společností v reakci na teroristické útoky páchané muslimy jsou ve Francii poměrně časté (viz níže). Návrh doprovázela zpráva, vytvořená vyšetřovacím výborem pro aplikaci principu laïcité, analyzující stav náboženství ve francouzské společnosti. Zdůrazňovala důležitost zachování francouzského republikánského ideálu oddělení církve od státu. Obsahovala doporučení zakázat na školách nošení muslimských šátků, židovských jarmulek a turbanů u sikhských chlapců. Na druhou stranu, doporučila komise povolit nošení diskrétních symbolů víry, jako jsou malé kříže, Davidovy hvězdy nebo ruce Fatimy (hamsa). Navíc výbor konstatoval, že považuje situaci, kdy ženy nosí muslimský závoj, za známku mužské nadvlády, která je v rozporu s francouzskými kulturními praktikami, založenými na „,sekulárních emancipačních normách “.68

65 Rozhodnutí Státní rady č. 346-893 z 27. listopadu 1989.

${ }^{66}$ MAZHER, M. I. Laïcité and the banning of the 'hijab' in France. Legal Studies. 2005, Vol. 25, No. 2, s. 260-295.

67 JONES, N. Beneath the Veil: Muslim Girls and Islamic Headscarves in Secular France. Macquarie Law Journal. 2009, Vol. 9, s. 56-57.

68 Assembleé nationale. Rapport d'information fait au nom de la mission d'information sur la question du port des signes religieux a l'école, $n^{\circ} 1275$ - tome II - 1ère partie. In: Assembleé nationale [online]. 2003 [cit. 2021-04-10]. Dostupné na: https://www.assemblee-nationale.fr/12/rapports/r1275-t2.asp. 
Zákon byl přijat v březnu 2004 a přezdívá se mu ,„sátkový zákon“. ${ }^{69} \mathrm{~V}$ čl. 1 zakazuje nošení symbolů nebo oděvů, kterými žáci zjevně projevují náboženskou př́slušnost. Stejně jako výše zmíněné rozhodnutí Státní rady, tak ani zákon neuvádí žádný taxativní/ demonstrativní výčet zakázaných/povolených symbolů. Je tedy předmětem široké interpretace. Výkladově jsou sem zařazeny výše zmíněné šátky, jarmulky, turbany i velké křest’anské křiže. Prakticky okamžitě po přijetí byl šátkový zákon napadán jako diskriminační předpis zaměřený jen na muslimy. Pravidlo v něm zakotvené lze považovat za vcelku neutrální, ale v souvislosti s velmi specifickými náboženskými pravidly islámu i k počtu jeho vyznavačů nelze pochybovat o tom, že nejvíce dopadlo právě na tuto skupinu.

Zákon i předchozí rozhodnutí byly několikrát napadeny před Evropským soudem pro lidská práva (dále jen „ESLP“) pro porušení čl. $9^{70}$ Úmluvy o ochraně lidských práv a základních svobod (dále jen „Úmluva“). ESLP však tuto francouzskou ústavní konstrukci podržel. Ve spojeném ř́zení ve věci Dogru proti Francii a Kervanci proti Francii ${ }^{71}$ ESLP rozhodoval o př́padu dvou muslimek, studujících v letech 1998-1999 na veřejné střední škole. Tedy v období před platností tzv. šátkového zákona. Obě děvčata chodila opakovaně na hodiny tělesné výchovy v šátcích a odmítala si je sundat, navzdory žádostem učitele. Disciplinární komise školy rozhodla o jejich vyloučení. Toto rozhodnutí bylo následně potvrzeno francouzskými soudy. ESLP judikoval, že ani $\mathrm{v}$ jednom případě nedošlo k porušení článku 9 Úmluvy. Shledal, že vnitrostátní orgány dospěly ke správnému závěru a že zákaz nošení islámského šátku do hodin tělocviku byl přiměřený z důvodu ochrany zdraví a bezpečnosti studentů. Připustil také, že uložený trest byl důsledkem odmítnutí stěžovatelek dodržovat pravidla platná v prostorách školy, o nichž byly rádně informovány.

V řízení ve věcech Aktas, Bayrak, Gamaleddyn, Ghazal, J. Singh a R. Singh proti Francii rozhodoval ESLP o vyloučení žákủ ze školy kvůli nošení nápadných symbolů náboženské př́slušnosti. ${ }^{72}$ Rozhodnutí bylo vydáno již po nabytí účinnosti šátkového zákona. Soud vyhlásil, že stížnosti jsou nepř́ipustné (zjevně neopodstatněné), přičemž rozhodl zejména o tom, že zásah do svobody projevu náboženství žáků byl předepsán zákonem a sledoval legitimní cíl ochrany práv a svobod ostatních i veřejného pořádku. Dále zdůraznil roli státu jako neutrálního organizátora působení různých náboženství a vyznání. Pokud jde o trest definitivního vyloučení, ani to dle ESLP nebylo nepřimě-

69 Loi n 2004-228 du 15 mars 2004 encadrant, en application du principe de laïcité, le port de signes ou de tenues manifestant une appartenance religieuse dans les écoles, collèges et lycées publics.

70 „Svoboda myšlení, svědomi a náboženského vyznání.

1. Každý má právo na svobodu myšlení, svědomi a náboženského vyznání; toto právo zahrnuje svobodu změnit své náboženské vyznání nebo přesvědčení, jakož i svobodu projevovat své náboženské vyznání nebo presvědčení sám nebo společně s jinými, at'veřejně nebo soukromě, bohoslužbou, vyučováním, prováděním náboženských úkonů a zachováváním obřadi̊.

2. Svoboda projevovat náboženské vyznání a přesvědčeni může podléhat jen omezením, která jsou stanovena zákony a která jsou nezbytná v demokratické společnosti v zájmu veřejné bezpečnosti, ochrany veřejného poŕádku, zdraví nebo morálky nebo ochrany práv a svobod jiných. “

71 Rozhodnutí ESLP ze dne 4. 12. 2008, ve věci Dogru proti Francii a Kervanci proti Francii, stížnost č. $27058 / 05$ a $31645 / 04$.

72 Rozhodnutí ESLP ze dne 17. 7. 2009, Aktas proti Francii, Bayrak proti Francii, Gamaleddyn proti Francii, Ghazal proti Francii, J. Singh proti Francii a R. Singh proti Francii, stížnosti č. 43563/08, 14308/08, 29134/08, 18527/08, 25463/08, 27561/08. 
řené sledovaným cílům, protože žáci měli možnost pokračovat ve školní docházce prostřednictvím korespondenčních kurzů. ESLP rozhodl podobně i v prípadech zákazi̊ v jiných zemích, např. ve věcech Dahlab proti Švýcarsku ${ }^{73}$ a Leyla Sahin proti Turecku. ${ }^{74}$

Šátky ve škole celý problém neskončil. Postupně se začalo řešit zakrývání obličeje i celé postavy na veřejnosti. Tato problematika je, na rozdíl od symbolů na školách, kde lze jednoznačně sledovat potřebu ochrany neutrálního názorového rozvoje žáků jako zvláště citlivé skupiny, mnohem komplikovanější. Obsahuje v sobě nejenom demonstraci přesvědčení a víry konkrétní osoby na veřejně př́stupných prostranstvích, v běžných životních situacích, jako jsou návštěvy parku, kina, divadla nebo nákup v obchodě, ale i vnášení těchto symbolů do dalších veřejných institucí, jako jsou soudy, státní úřady, možnost nosit náboženské symboly na fotce ve veřejných dokumentech a listinách apod. Spojujícím prvkem všech těchto aspektů je nejenom veřejný pořádek, ale v širším slova smyslu snaha o pokojné soužití různých náboženských skupin (vivre ensemble).

Celá diskuse je však od počátku zjevně deformována $\mathrm{v}$ zásadě neslučitelnými postoji. Jedna strana sporu, reprezentovaná zejména tzv. „levicovými progresivisty“, nejčastěji z akademického prostředí, tvrdí, že zahalování, resp. zahalující oděv, je ve své podstatě jenom běžným oblečením, o jehož použití si muslimské ženy rozhodují svobodně. Druhá strana, označovaná „progresivisty“ za „pravicové xenofobní extremisty“, naopak říká, že tento způsob oblékání ukazuje jednoznačně na podřízenost muslimek a reprezentuje zásadní podmínku, bez jejíhož respektování muslimské ženy (významná část z nich) nemohou vůbec veřejný prostor sdílet. Resp. je jim to upíráno muslimskými muži s odvoláním na náboženská pravidla. Sám autor se přiklání k pozici druhé, aniž by se cítil být „pravicovým xenofobním extremistou“.

V důsledku globální ekonomické krize z let 2008-2015 došlo k dalšímu masivnímu nárůstu imigrace do Francie. To vedlo k posílení nacionalistických tendencí. Sekularismus je v dnešní Francii velmi často podporován právě z kruhủ spojovaných $\mathrm{s}$,protiislamizací“ ${ }^{75}$ Francouzský parlament zahájil první vyšetřování výskytu náboženských symbolů na veřejnosti krátce poté, co tehdejší prezident Sarkozy v červnu 2009 uvedl, že ve Francii nejsou vítány náboženské závoje a že zákon by měl chránit ženy před nucením zakrývat si tváŕ a musí podporovat francouzské sekulární hodnoty. ${ }^{76}$ Dne 14. ř́jna 2010 byl přijat zákon zakazující zakrývání obličeje na veřejných prostranstvích ${ }^{77}$ (dále jen „zákon zakazující zakrývání obličeje“). Čl. 2 odst. 1 zákona definuje veřejný prostor velmi široce. $V$ podstatě jako jakýkoliv prostor mimo domov. Dle vágně konstruovaného čl. 1 se vztahuje prakticky na jakékoliv oděvy, masky, přilby, punčochy, kukly či šátky, které zakrývají obličej, pokud se používají samostatně nebo ve spojení s jiným oděvem. Avšak čl. 2 odst. 2 zákona poskytuje velmi dlouhý seznam

\footnotetext{
73 Rozhodnutí ESLP ze dne 15. 2. 2001, Dahlab proti Švýcarsku, stížnost č. 42393/98.

74 Rozhodnutí ESLP ze dne 10. 11. 2005, Leyla Şahin proti Turecku, stížnost č. 44774/98.

75 BAUBÉROT, J. La Laïcité falsifiée. Paris: La Découverte, 2012.

76 President Sarkozy says 'no place' for burqa in secular France. In: France 24 [online]. 12. 11. 2009 [cit. 2021-04-15]. Dostupné na: https://www.france24.com/en/20091112-president-sarkozy-says-no-place -burqa-secular-france.

77 Loi n ${ }^{\circ} 2010-1192$ du 11 octobre 2010 interdisant la dissimulation du visage dans l'espace public.
} 
výjimek, kdy se povinnost nezakrývat si obličej nepoužije. ${ }^{78}$ Jednou z nich jsou i zdravotní důvody. Je tedy legální zakrývat si obličej na veřejnosti např. rouškou. Zákaz se samozřejmě nevztahuje výhradně na muslimy, ale nošení burky ${ }^{79}$ a nikábu ${ }^{80}$ postihuje. Podle některých islámských učenců je nošení nikábu u žen povinností, jiní zase jeho nošení považují pouze za chvályhodné. ${ }^{81} \mathrm{~V}$ obecné rovině, nejednotnost pravidel náboženského života muslimské obce je dalším z problémů, které komplikují možnost státu limity náboženské svobody jasně vymezit, ale je i překážkou pokojného soužití muslimů s vyznavači jiných, ,centralizovanějších“ náboženství. Dle čl. 3 zákona se nedodržení zákazu trestá pokutou, případně i povinností účastnit se občanské výchovy, která může být uložena současně, nebo místo pokuty. Zákon se vztahuje na všechny osoby, které se nacházejí na francouzském území, bez ohledu na jejich občanský status, pohlaví, věk či národnost. Tedy i na turisty. ${ }^{82}$

Jak je vidět, zákon zakazující zakrývání obličeje má daleko širší společenský dopad než zákon šátkový, který je úzce zaměřen pouze na oblast vzdělávání. Je potřeba zmínit i to, že na rozdíl od šátkového zákona nehovoří explicitně o nošení náboženských symbolů, ani svou textací ničím neodkazuje k ústavnímu principu lä̈cité. Navíc, šátkový zákon ještě před potrestáním studenta, který porušuje zákaz, předpokládá nejprve jednání školy se studentem a jeho rodiči. U zákona zakazujícího zakrývání obličeje nastupuje sankce automaticky, ihned po zjištění porušení zákazu. Co se týká jeho společenského dopadu, vzhledem k jeho konstrukci a k tomu, co se ukázalo po přijetí šátkového zákona, je zjevné, že nejvíc postihne opět muslimskou komunitu.

Podobné zákony byly následně přijaty v mnoha dalších evropských zemích, např. v Rakousku (2017 - zákaz zakrývat si obličej na veřejných místech nebo ve veřejných budovách ${ }^{83}$ ), Belgii (2011 - zákaz nošení oblečení, které zcela nebo výrazně zakrývá obličej na veřejných prostranstvích $\left.{ }^{84}\right)$, Nizozemí (2012 - částečný zákaz nošení oděvů zakrývajících obličej ve vzdělávání, veřejné dopravě, vládních budovách a zdravotní péči ${ }^{85}$ ). Mezi evropské země, kde je v řadě povolání nebo v některých regionech tento zákaz zakotven alespoň částečně, patří např. i Německo, Itálie, Španělsko, Dánsko, Norsko, Švédsko, Lotyšsko nebo Švýcarsko. ${ }^{86}$ Zákony jsou zde relativně stručné, obecné a většinou vychází z francouzského vzoru. To se týká např. i výše pokut.

78 Pokud je oblečení předepsáno nebo povoleno legislativními nebo regulačními ustanoveními, pokud je odůvodněno ze zdravotních nebo profesionálních důvodů nebo pokud je součástí sportovního úboru, na festivalech nebo uměleckých či tradičních událostech - v případě účinkujících.

79 Burka pokrývá celé tělo a má pouze úzkou štěrbinou pro oči pokrytou gázou.

80 Nikáb je ekvivalent burky, je za ni často zaměňován. Jedná se o závoj, který poskytuje pouze úzký otvor pro oči. Ženy k nikábu často nosí tzv. abáju, oděv, jenž kryje celé tělo, a právě kombinace s nikábem připomíná burku.

81 SNYDER, R. E. Liberté Religieuse en Europe: Discussing the French Concealment Act. Human Rights Brief. 2011, Vol. 18, No. 3, s. 14-16.

82 Tamtéž, s. 15.

83 Bundesgesetz über das Verbot der Verhüllung des Gesichts in der Öffentlichkeit (Anti Gesichtsverhüllungsgesetz - AGesVG) StF: BGBl. I Nr. 68/2017.

${ }^{84}$ Loi du 1er juin 2011 visant à interdire le port de tout vêtement cachant totalement ou de manière principale le visage; Publié le: 2011-07-13.

85 Wet van 27 juni 2018, houdende instelling van een gedeeltelijk verbod op het dragen van gezichtsbedekkende kleding in het onderwijs, het openbaar vervoer, overheidsgebouwen en de zorg (Wet gedeeltelijk verbod gezichtsbedekkende kleding); Staatsblad 20182222.

86 Rozhodnutí ESLP ze dne 15. 2. 2001, Dahlab proti Švýcarsku, stížnost č. 42393/98. 
Ještě před nabytím účinnosti samotného zákona rozhodovala 7. ř́ijna 2020 o jeho ústavnosti Ústavní rada. Ta jej v rozhodnutí č. 2010-613 DC prohlásila za ústavní. V rozhodnutí uvedla: ,Vzhledem $k$ tomu, že účelem článků 1 a 2 uvedeného zákona je reagovat na doposud extrémně vzácné praktiky, spočivající v utajováni tváre na veřejných prostranstvích; a vzhledem k tomu, že zákonodárci se domnivali, že tyto praktiky mohou představovat nebezpečí pro veřejnou bezpečnost a narušovat minimální požadavky na život ve společnosti; že zákonodárce rovněž predpokládá, že ženy, které se dobrovolně nebo nedobrovolnè skrývají, se dostávaji do situace vyloučení a ménécennosti, která je zjevně neslučitelná s ústavnimi zásadami svobody a rovnosti; že přijetím uvedených ustanoveni zákonodárci dokončili a zobecnili pravidla na ochranu veřejného pořádku, která byla dosud vyhrazena pouze konkrétním situacím [...] Zákaz zakrytí obličeje na veřejnosti však nemůže vést $k$ omezeni výkonu náboženské svobody na veřejně př́stupných mistech, aniž by to mělo nepríznivý dopad na článek 10 Deklarace práv člověka a občana. S touto kvalifikací nejsou oddily 1 až 3 posuzovaného zákona protiústavní. "87

Následně byl zákon vystaven kontrole ESLP. V případu S.A.S. proti Francii ${ }^{88}$ řešil stížnost praktikující muslimky, která si stěžovala na to, že dle zákona zakazujícího zakrývání obličeje již nesmí nosit na tváři závoj. Stěžovatelka tvrdila, že jako muslimka nosila burku a nikáb v souladu se svou náboženskou vírou, kulturou a osobním přesvědčením, a to dobrovolně, bez nátlaku manžela a rodiny. Také uvedla, že jejím cílem nebylo obtěžovat nošením šátku ostatní, ale cítit vnitřní mír sama se sebou. Dále tvrdila porušení čl. $8{ }^{89} 9$ a $14^{90}$ Úmluvy, tedy práva na respektování rodinného a soukromého života, svobody myšlení, svědomí a náboženského vyznání a zákazu diskriminace. ESLP neshledal ze strany Francie porušení čl. 8 ani čl. 9 a zdůraznil, že respektování podmínek soužití bylo legitimním cílem dotčeného zákona a stát má v tomto př́ípadě velký manévrovací prostor (,,široký prostor pro uváženi “). Soud uvedl, že snaha zajistit dodržování minimálních záruk života ve společnosti může být považována za prvek ochrany práv a svobod druhých a že zákaz je v zásadě ospravedlnitelný pouze v rozsahu, v němž se snaží zaručit podmínky soužití. Pokud jde o politickou otázku, u níž existují značné rozdíly v názorech, zákaz uložený zákonem ze dne 11. ř́ijna 2010 neporušil Úmluvu. Soud rovněž rozhodl, že nedošlo ani k porušení čl. 14, ve spojení s čl. 8 nebo 9 Úmluvy. Konstatoval, že zákaz zakrývání obličeje měl sice nepochybně konkrétní negativní dopady na situaci muslimských žen ve Francii, ale toto opatření mělo objektivní a rozumné odůvodnění. $V$ novějším rozhodnutí, v případu Belcacemi

87 Rozhodnutí Ústavní rady č. 2010-613 DC ze 7. ř́ijna 2010.

88 Rozhodnutí ESLP ze dne 26. června 2014, S.A.S. proti Francii, stížnost č. 43835/11.

89 „Právo na respektování rodinného a soukromého života

1. Každý má právo na respektováni svého soukromého a rodinného života, obydli a korespondence.

2. Státni orgán nemůže do výkonu tohoto práva zasahovat kromě př́padů, kdy je to v souladu se zákonem a nezbytné v demokratické společnosti v zájmu národní bezpečnosti, veřejné bezpečnosti, hospodářsého blahobytu země, predcházeni nepokojiom a zločinnosti, ochrany zdraví nebo morálky nebo ochrany práv a svobod jiných."

90 „Zákaz diskriminace

Uživáni práv a svobod přiznaných touto Úmluvou musí být zajištěno bez diskriminace založené na jakémkoli důvodu, jako je pohlaví, rasa, barva pleti, jazyk, náboženství, politické nebo jiné smýšlení, národnostní nebo sociální pưvod, př́slušnost k národnostni menšině, majetek, rod nebo jiné postaveni. “" 
a Oussar proti Belgii ${ }^{91}$ u podobného belgického zákona, se ESLP odkázal na své závěry z rozhodnutí ve věci S.A.S. proti Francii a dále k zákazu šátku na veřejnosti konstatoval, že dle jeho názoru je cílem omezení zaručit podmínky „společného života“ a ochrany práv a svobod druhých a že je to $\mathrm{v}$ demokratické společnosti nezbytné.

Je zjevné, že na rozdíl od šátkového zákona u zákona zakazujícího zakrývání obličeje je k odůvodnění jeho nezbytnosti soudy i zákonodárcem podstatně více akcentovaná otázka veřejného pořádku a bezpečnosti než princip sekularismu a laïcité. Lze i uznat, že po přijetí zákona se věřící některých náboženství dostali pod silný tlak. Je potřeba vidět i rozdíly. Např. v př́padě Leyla Sahin proti Turecku ESLP posuzoval situaci v Turecku, kde, až na některé specifické akademické situace, mohly muslimské ženy šátek nadále běžně nosit. Ve věci Dogru proti Francii škola zakázala nosit šátky pouze během tělesné výchovy. Podobně v př́ípadu Dahlab proti Švýcarsku bylo omezení nošení šátku aplikováno výhradně na školu. V každém z těchto príípadů je potvrzený zákaz specifický a umožňuje jednotlivci projevit víru ve většině životních situací. Veřejným zákazem zakrývání obličeje na většině míst mimo domov a bohoslužby se forum externum věřících určitě zásadním způsobem zúžilo.

Přijetím zákona však celá problematika nebyla ani zdaleka uzavřena. Novým bojištěm se stala např. debata o podávání vepřového masa $\mathrm{v}$ jídelnách francouzských veřejných škol a obecně halal jídlo. Čím dál častěji se množí případy, kdy muslimští rodiče vyžadují po zřizovateli, aby bylo ve škole servírováno halal jídlo nebo aby některé potraviny nebyly ve školních jídelnách podávány vůbec. Zakládají kvůli tomu i nátlakové spolky. ${ }^{92}$ Nevyhovění těmto požadavkům vede často ke vzdělávání žáků mimo školní výuku, resp. k zakládání soukromých škol zaměřených na muslimy. Dalším modelovým př́kladem je tlak na plošné povolení tzv. burkin, tzn. celotělového oděvu, ekvivalentu plavek určeného muslimským ženám. Ty byly zakázány vyhláškami na řadě veřejných koupališt', např. v Grenoblu, ${ }^{93} \mathrm{~s}$ odvoláním na sekularismus, po teroristických útocích $\mathrm{v}$ roce 2015.

Problém francouzského vztahu k muslimské komunitě souvisí nepochybně i s otázkou bezpečnosti. Jedním z častých argumentů zastánců zákazu nošení muslimských šátků na veřejnosti je to, že jsou velmi jednoduše zneužitelné pro páchání trestné činnosti. Pod burkou a nikábem, jejichž účelem je zakrýt „křivky“ postavy ženy zcela, se dá jednoduše ukrýt zbraň nebo pás s výbušninami. Zakrytí obličeje šátkem znemožňuje i jakoukoliv identifikaci, v podstatě včetně jasného určení pohlaví.

Historie náboženského extremismu ve Francii je bohatá a souvisí s její koloniální minulostí. V 80. letech 20. století došlo ve Francii k sérii teroristických útoků kvůli francouzské účasti v libanonské občanské válce. V 90. letech zde útočila organizace

91 Rozhodnutí ESLP ze dne 11. července 2017, Belcacemi a Oussar proti Belgii, stížnost č. 37798/13.

92 CHRISAFIS, A. Pork or nothing: how school dinners are dividing France. The Guardian [online]. 13. 10. 2015 [cit. 2021-04-17]. Dostupné na: https://www.theguardian.com/world/2015/oct/13/pork-school -dinners-france-secularism-children-religious-intolerancehttps://www.theguardian.com/world/2015 /oct/13/pork-school-dinners-france-secularism-children-religious-intolerance.

93 GREGORY, A. French city closes public swimming pools after Muslim women defy burkini ban in protest. Independent [online]. 28. 6. 2019 [cit. 2021-04-18]. Dostupné na: https://www.independent.co.uk/news /world/europe/swimming-pool-closed-burkini-ban-france-grenoble-muslim-protest-a $8978836 . \mathrm{html}$. 
Alžírská ozbrojená islámská skupina. ${ }^{94}$ Mezi lety 1990 až 2012 čelila Francie opakovaným útokům, spojeným s mezinárodním islámským džihádistickými hnutím, včetně krvavých útoků provedených M. Merahem v roce $2012 .{ }^{95}$ Naštěstí, rozsahem se jednalo o nekoordinované útoky menšího rozsahu. Zlom přišel v roce 2015. Dva útoky, ke kterým se přihlásil tzv. Islámský stát, zanechaly ve vědomí francouzské společnosti hlubokou ránu a odstartovaly nové kolo diskusí o principu laïcité. Tuto debatu začala pro vlastní politické účely využívat převážně tzv. „extrémní pravice“ pod vedením strany Rassemblement national. Dne 7. ledna 2015 muslimští džihádisté zaútočili na francouzský satirický časopis Charlie Hebdo a zabili 12 reportérů. O několik dní později další atentátník postřílel pět lidí v košer supermarketu v Paříži. A ještě téhož roku, v listopadu 2015, se ve Francii udál nejkrvavější teroristický útok od roku 1945. Ozbrojenci na různých místech Paříže zaútočili koordinovaně na kavárny, restaurace, národní stadion i na koncertní sál Bataclan. Útok způsobil smrt 130 lidí. Znovu se k němu přihlásil tzv. Islámský stát. Další útok této organizace následoval v roce 2016 ve městě Nice, kde zemřelo 87 lidí. $^{96}$

$\mathrm{K}$ teroristickým útokům menšího rozsahu spojeným s náboženským extremismem dochází ve Francii prakticky dodnes. $\mathrm{O}$ tom, co přesně je příčinou radikalizace některých muslimů, se vedou dlouhé a ostré debaty. Rozhodně není ambicí této práce popsat všechny. Každopádně, $\mathrm{k}$ těm nejčastějším zmiňovaným patří teorie kognitivní radikalizace islámu. Podporuje ji např. Gilles Kepel. ${ }^{97}$ Oproti ní stojí teorie Oliviera Roye, který upozorňuje na strukturální nerovnosti ve společnosti, které generují radikální, a tedy i islamistické postoje. Mnoho muslimských přistěhovalců je chudých, s nízkými př́ijmy, žijí na okraji větších měst, na místech plných každodenního násilí. ${ }^{8}$ Postupný vznik těchto oblastí, kde se jen velmi složitě prosazuje právní rád státu, je ve Franci nazýván ghettoïsation. François Burgat si naopak myslí, že islamistická radikalizace je hlavně důsledkem konfliktů identity a je spojená s historií francouzského kolonialismu. ${ }^{99}$ Jiní autoři zase mluví o tom, že se radikálové rekrutují převážně z řad obyvatelstva s psychickými problémy. Každopádně, at' už je hlavní prríčinou kterákoliv z výše uvedených, faktem je, že sílící extremismus spojovaný s islámem změnil radikálně i celospolečenskou debatu o principu sekularismu a laïcité.

Ihned po svém nástupu do funkce v roce 2017 se současný francouzský prezident Macron zavázal, že komplexně vyřeší vztah francouzského sekularismu k tzv. politickému islámu. Trvalo více než tři roky, než představil v říjnu roku 2020 návrh zákona na posílení sekularismu a upevnění republikánských principů (dále jen „separační zákon“). ${ }^{100}$ Návrh byl představen dne 9. prosince 2020. Tedy týden poté, co byl v komuně Conflans Saint-Honorine zabit učitel za předchozí prezentaci karikatur proroka Moha-

94 KEPEL, G. Jihad: the Trail of Political Islam. Cambridge: Harvard University Press, 2002, s. 265-270.

95 SCHWARZENBACH, c. d., s. 24.

96 Tamtéž, s. 24-25.

97 KEPEL, G. Terreur dans l'Hexagone: genèse du djihad français. Paris: Gallimard, 2015.

98 ROY, O. EuroIslam: the jihad within? The National Interest. 2003, Vol. 71, s. 63-73.

99 BURGAT, F. Comprendre l'islam politique: une trajectoire de recherche sur l'altérité islamiste, 1973-2016. Paris: La Découverte, 2016.

${ }^{100}$ Projet de loi visant à renforcer la laïcité et conforter les principes républicains. 
meda během výuky tematicky se věnující svobodě projevu, ${ }^{101}$ a přesně 115 let od přijetí odlukového zákona z roku 1905. Prezident ve svém vystoupení uvedl: „Problém není sekularismus, sekularismus je svoboda věrit nebo nevěrit, možnost praktikovat svoji víru tehdy, kdy je zajištěn veřejný pořádek. Sekularismus je neutralita státu a v žádném prípadě to neznamená vymazání náboženství z veřejného prostoru. Sekularismus je tmel pro sjednocení společnosti ve Francii. [...] Problém je islamistický separatismus. Je to vědomý politicko-náboženský projekt, který se vyznačuje tím, že se opakovaně odchyluje od hodnot republiky. Výsledkem je jakási oddèlená proti-společnost, která se vyznačuje tím, že její dèti se neúčastni francouzského vzdělávacího systému a vytvárí si vlastní oddělené sportovni a kulturní akce. Zároveñ tito lidé argumentuji tím, že si jen vytvář́ vlastní kulturu uvnitř Francie, nicméně tato kultura není v souladu s právními predpisy republiky. Jedná se o indoktrinaci, která popírá základni principy, jako je rovnost mužů a žen či lidská důstojnost. Jejich zákony se tvárí, že jsou nadřazeny zákonům republiky. " 102 Podle ministerstva vnitra je zákon výsledkem , důkladné právní práce, terénnich výzkumů a rozsáhlých konzultaci s úředniky, zástupci církví a náboženských společností, akademiků a intelektuálů [...] Ambici tohoto textu je umožnit republice jednat proti těm, kteř́ ji chtějí destabilizovat, aby se posílila národní soudržnost. "103

Návrh má dva hlavní cíle. Zaměřuje se na zajištění dodržování zákonů a zásad republiky ve všech oblastech vystavených riziku separatistického vlivu a na garantování neutrality ze strany státních orgánů. Svými 51 články předčí dokonce i odlukový zákon 1905, který zásadně rozvijí. Nejstěžejnějším ustanovením je čl. 21 o rodinné výchově. Jen $\mathrm{k}$ němu bylo v Národním shromáždění předloženo celkem 400 pozměňovacích návrhů. Stanovuje zásadu povinného prezenčního vzdělávání pro všechny děti, které podléhají povinné školní docházce. Od povinnosti docházet do veřejného nebo soukromého vzdělávacího zařízení se lze zprostit výhradně jen se souhlasem organizace Akademických ředitelů vnitrostátních vzdělávacích služeb (dále jen „DASEN“). ${ }^{104}$ Domácí vzdělávání je dle čl. 2 odst. 2 návrhu možné jen při splnění taxativně vymezených podmínek a z taxativně vymezených důvodů, mezi které patří zdravotní stav nebo zdravotní postižení dítěte, profesionální sportovní nebo intenzivní umělecká činnost dítěte, „kočování“ rodiny napříč Francií, prrípadně vzdálenost školy od bydliště dítěte. Avšak výhradně za předpokladu, že zákonní zástupci dítěte prokážou svou schopnost poskytovat rodinné vzdělávání při respektování nejlepších zájmů dítěte. Dle odst. 3 stejného článku, pokud je povolení získáno podvodem, je bezodkladně odňato. Př́slušný státní orgán upozorní osoby odpovědné za dítě, že jsou povinné do 15 dnů od doručení rozhodnutí o odnětí povolení zapsat ho do veřejného nebo soukromého vzdělávacího zařízení a neprodleně

${ }^{101}$ BESWICK, E. Demonstrations throughout France in tribute to beheaded teacher. In: Euronews [online]. 19. 10. 2020 [cit. 2021-04-18]. Dostupné na: https://www.euronews.com/2020/10/16/man-decapitated -near-paris-police-confirm-to-euronews.

102 Élysée. La République en actes: discours et conférence de presse du Président depuis Les Mureaux. In: YouTube video [online]. 27. 02. 2007 [cit. 2021-04-18]. Dostupné na: https://www.youtube.com/watch $? \mathrm{v}=\mathrm{dcIDKr} 9 \mathrm{~mJ} 7 \mathrm{c}$.

${ }^{103}$ Compte rendu du Conseil des ministres du 9 décembre 2020. Projets de loi. Respect des principes de la République. In: Gouvernement: Liberté, Egalité, Fraternité [online]. 2020 [cit. 2021-04-20]. Dostupné na: https://www.gouvernement.fr/conseil-des-ministres/2020-12-09\#respect-des-principes-de-la-republique.

${ }^{104}$ D'académie-directeurs des services départementaux de l'éducation nationale svojí konstrukcí a pravomocemi v podstatě odpovídá České školní inspekci. 
o tom informovat starostu, který následně informuje př́slušný státní orgán, školu nebo zařízení, které si rodiče vybrali. Dále návrh posiluje dohled nad soukromými školami, zejména zavedením možnosti ,administrativního uzavření“" $\mathrm{v}$ případě systematického porušování podmínek vzdělávacího programu. Státem uznané sportovní federace přecházejí z režimu dohledu do režimu kontroly. Do podmínek schválení federací má být zahrnut závazek „respektování zásad a hodnot republiky“. Poslanci do návrhu přidali navíc i trestný čin maření funkce učitele. Čl. 18 návrhu separačního zákona vytváŕí nový trestný čin ohrožení života ostatních zveřejněním osobních údajů na internetu. Ten byl přidán s ohledem na výše zmíněnou vraždu učitele Samuela Patyho.

Čl. 1 návrhu uvádí, že zásada neutrality se vztahuje na všechny osoby veřejného i soukromého práva, které na základě zákona nebo smlouvy zajišt’ují výkon veřejné služby. V této souvislosti se nejedná jen o výkon veřejné moci, ale i o poskytování jakékoliv veřejnosti př́stupné služby. $\mathrm{V}$ průběhu zasedání byla působnost zákona rozšířena na všechny služby veřejné osobní dopravy, včetně vlaků TGV, i na služby sociální. Ustanovení směřuje rovněž do poskytování zdravotních služeb. ${ }^{105}$ Stále více se totiž vyskytují př́pady, kdy pacient nebo jeho doprovod s odvoláním na náboženské důvody odmítne plánovaný lékařský úkon nebo účast personálu, zejména kvůli pohlaví. Konstrukce tohoto článku vychází z doporučení tzv. Rossinotovy zprávy o stavu sekularismu ve veřejných službách z roku 2006. ${ }^{106}$ Návrh zákona zakazuje všem zdravotníkům vydávat tzv. osvědčení o panenství s trestem odnětí svobody až na jeden rok a pokutou do výše 15.000 EUR.

Čl. 4 si klade za cíl potrestat až 5 lety odnětí svobody a pokutou ve výši 75.000 EUR každého, kdo vyhrožuje, napadne nebo zastrašuje voleného zástupce nebo úředníka veřejné služby. Poslanci rovněž zavedli kriminalizaci všech forem nátlaku z okolí ženy. Text posiluje postihování polygamie. $V$ rámci boje s praktikou tzv. nucených sňatků má př́slušný úředník dle čl. 17 návrhu povinnost setkat se odděleně s budoucími manžely vždy, pokud existují sebemenší pochybnosti o svobodné povaze sňatečného souhlasu jednoho z nich. $V$ případě přetrvávajících pochybností může postoupit záležitost prokurátorovi.

Dle čl. 6 návrhu separačního zákona jakákoli žádost o grant $\mathrm{z}$ veřejných prostředků bude předmětem závazku ze strany žadatele $\mathrm{k}$ respektování zásad a hodnot republiky (mezi které patří svoboda, rovnost, bratrství a úcta $\mathrm{k}$ důstojnosti lidské osoby, jakož i k respektování veřejného pořádku a pokojného soužití). Dále rozšiřuje možné důvody pro zrušení sdružení. Po vzoru např. českého zákona o trestní odpovědnosti právnických osob ${ }^{107}$ bude možné postihovat sdružení za činy spáchané jeho členy v př́mé vazbě na činnost tohoto sdružení. Čl. 3 rozšiřuje registr pachatelů teroristických trestných činů

${ }^{105}$ Ce que contient le projet de loi contre le « séparatisme » examiné par l'Assemblée. Le Monde [online]. 1.2. 2021 [cit. 2021-04-18]. Dostupné na: https://www.lemonde.fr/politique/article/2021/02/01/instruction -a-domicile-haine-en-ligne-neutralite-du-service-public-ce-que-contient-le-projet-de-loi-contre-le -separatisme-examine-par-les-deputes_6068402_823448.html?fbclid=IwAR35sWpmK12UghmpWcH6 W80G0LqLUa-HPs88ynrQZnTxW2nIQ_kvYNḦ01OM.

106 ROSSINOT, A. La laïcité dans les services publics: rapport du Groupe de Travail [online]. 13.9. 2006, s. 22 [cit. 2021-04-18]. Dostupné na: https://www.fonction-publique.gouv.fr/files/files/statut_et_remunerations

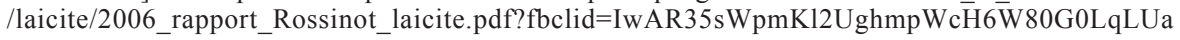
-HPs88ynrQZnTxW2nIQ_kvYNH̄01OM.

107 Zákon č. 418/2011 Sb., o trestní odpovědnosti právnických osob a řízení proti nim. 
o skutky související se schvalováním a podněcování $\mathrm{k}$ terorismu. Pachatelům uvedeným v registru je zakázáno vykonávat funkci, ve které by přicházeli do kontaktu s veřejností. Soud může navíc vyslovit i zákaz účasti na bohoslužbách, a to v případě odsouzení pachatele za podněcování $\mathrm{k}$ teroristickým činům nebo při podněcování $\mathrm{k}$ diskriminaci, nenávisti nebo násilí. Ustanovení mírí např. na situace, kdy imám ve svém kázání vyzývá věřící k páchání trestné činnosti, př́ípadně ji ex post schvaluje. Ve své podstatě jde o moderní obdobu „kazatelnicového paragrafu“.

K vysvětlení dalšího klíčového ustanovení je nutné krátce osvětlit převažující způsob financování muslimských náboženských sdružení ve Francii. Čl. 2 odlukového zákona 1905 vylučuje financování ze strany státu a samosprávy pro jakýkoliv kult. Vzhledem k tomu, že muslimská komunita nedisponovala historicky ve Francii žádným rozsáhlým majetkem, ze kterého by mohla financovat provoz kultu, př́padně výstavbu mešit, rozmohl se zde systém, kdy je vše financováno především ze zahraničních zdrojů. Převážně z konzervativních muslimských států, jako jsou Turecko, Saudská Arábie, země Perského zálivu a severní Afriky. Donoři se pak snaží udržet si nad financovanými komunitami kontrolu a vliv zejména tím, že na místa kazatelů prosazují vlastní občany. To pro stát logicky představuje naprosto zásadní problém, protože je tak uvnitř jeho území plíživě budována „pátá kolona“ občanů cizích zemí, reprezentujících z významné části islámský fundamentalismus a radikalismus. Čl. 35 návrhu separačního zákona proto obohacuje původní konstrukci o povinnost sdružení deklarovat př́slušnému správnímu orgánu veškeré částky přijaté ze zahraničí přesahující limit 10.000 EUR. V př́ípadě porušení této povinnosti, v souladu s odst. 14 stejného článku, může být uložena pokuta 3.700 EUR a její výše může být, v př́ípadě přitěžujících okolností, navýšena až na $25 \%$ z celkové výše nepřiznaného daru. Fyzickým nebo právnickým osobám hrozí dodatečný trest propadnutí celé nepřiznané částky.

Dle čl. 44 je možné, aby policejní prefekt uzavřel až na dva měsíce místa bohoslužeb (mešity), u kterých se prokáže, že zde dochází ke kázání myšlenek a teorií podporujících aktivity směřující $\mathrm{k}$ násilnostem a nenávisti, anebo které tyto násilnosti ospravedlňují. Porušení této uzávěry se trestá odnětím svobody na 6 měsíců a pokutou 7.500 EUR. ${ }^{108}$ Poslanci Národního shromáždění odhlasovali 347 hlasy pro, 151 proti návrh zákona o separatismu dne 16. února 2021. Senát, kde pravice dominuje, přijal návrh dne 12. dubna 2021, 208 hlasy pro, 109 senátorů bylo proti. Doplnili ho o pozměňovací návrh, zakazující nošení náboženských symbolů, zejména šátků zakrývajících obličej, pro osoby účastnící se školních výletů. O podobě konečného textu rozhodne jednání společného výboru obou komor. $V$ prípadě neúspěchu bude $\mathrm{v}$ každé $\mathrm{z}$ komor parlamentu provedeno další čtení. Poslední slovo bude mít Národní shromáždění. ${ }^{109}$ Proti závěrečnému schválení bojuje řada petic, které již nasbíraly desítky tisíc podpisů. Např. Retrait

${ }^{108}$ Projet de loi confortant le respect des principes de la République (INTX2030083L). In: République Française: Liberté, Egalité, Fraternité: Légifrance [online]. 2020 [cit. 2021-04-20]. Dostupné na: https:// www.legifrance.gouv.fr/dossierlegislatif/JORFDOLE000042635616/?detailType=CONTENU\&detail $\mathrm{Id}=1$.

${ }^{109}$ Le Sénat vote une version de la "loi séparatisme" nettement durcie par la droite. In: France 24 [online]. 13. 4. 2021 [cit. 2021-04-18]. Dostupné na: https://www.france24.com/fr/france/20210413-le-sénat-vote -une-version-de-la-loi-séparatisme-nettement-durcie-par-la-droite?fbclid=IwAR1HBuz_S22t4vni2nh AXkRsxozJkZdisE_i5gje7CpkSFFDLJV5dfziOgY. 
de la loi séparatisme, kterou organizuje Koalice za svobodu sdružování. ${ }^{110}$ Protestu se účastní i mladé muslimské ženy, které pod zkratkou \#PASTOUCHEAMONHIJAB bojují proti návrhu na sociálních sítích a spojují jej s otázkou feminismu a diskriminací žen. ${ }^{111}$

Je zjevné, že šance na oboustranně přijatelný kompromis je minimální. Vztahy s muslimskými menšinami se posledních několik let pomalu zhoršují napříč celou Evropou, i když ve Francii je to znát nejvíce. Jedna z příčin spočívá v tom, že lidskoprávní agendu do jisté míry „zcizili“ různí „aktivisté“, kteří pod záminkou obrany liberálních hodnot zcela oddělili agendu práv od debaty o povinnostech a odpovědnosti. Přitom právo a povinnost představují dvě strany jedné mince. Není to však jen problém Francie. Evropa jako celek zpohodlněla a ideově se vyprázdnila. Chybí jí sjednocující idea. Hodnoty, mezi které patří i přesně vymezená náboženská svoboda, odmítáme bránit, protože již ztratily jakýkoliv smysluplný obsah. Evropská politika se stala oportunistickou a v agendě obhajoby i těch nejzákladnějších hodnot a tradic naprosto selhává (i přs četné opačné politické proklamace). Krok za krokem ustupuje tlaku „politického islámu“ a odmítá si přiznat, že bezbřehý „lidskoprávní aktivismus“, ve který se zvrhla legitimní obhajoba lidských práv a svobod, je zjevně jednou z příčin, proč vznikla paralelní evropská společnost, která dnes již zcela otevřeně odmítá akceptovat evropské právo, kulturu i tradice. Jakékoliv snahy o úpravu azylové, př́padně lidskoprávní legislativy, jsou sabotovány. Svoji úlohu v tom bezesporu hrají jak vnitrostátní, tak i mezinárodní soudy. Kontinentální právo, které se vždy tvořivě přizpůsobovalo měnícím se společenským podmínkám, poslední desetiletí tvrdošíjně odmítá reagovat na negativní tendence, korelace i kauzality, spojené s migrací a masovým šířením islámu. Zcela se vytratilo povědomí, na kterém stojí základ jakékoliv odluky v našem prostoru, tzn. že francouzská, evropská ani česká legislativa nepochází od Boha, ale je pouze dílem člověka. Zdá se, že po sérii tragických událostí začíná Francie pomalu chápat, že se její př́stup i právní řád budou muset radikálně změnit. Je však otázkou, jestli snaha Francouzů napravit legislativní ofenzívou ,pět minut po dvanácté“ to, co je dle autora problémem spočívajícím v samotném jádru liberalismu, k něčemu smysluplnému povede. Autor se ztotožňuje s názorem prezidenta Masaryka a Emanuela Rádla, že problémem je, že liberalismus sám o sobě představuje vyprázdněný pojem a ,, [1]iberál háji kdejaké bláznivé přesvědčení, ale sám žádné nemá ". ${ }^{112}$ A to je část jádra problému, se kterým se Francie v současnosti potýká. Nejhorší možný důsledek liberalismu je pak společenská lhostejnost, kterou dnes všude okolo vidíme.

S ohledem na vše výše uvedené se autor domnívá, že Francii čeká v prríštích letech další krize. Zároveň je i toho názoru, že minimálně odborná veřejnost by již měla koneč-

${ }^{110}$ Retrait de la loi séparatisme. In: La Coalition pour les Libertés Associatives [online]. 9. 2. 2021 [cit. 2021-04-22]. Dostupné na: https://www.lacoalition.fr/Signez-la-petition-Et-si-la-loi-separatisme -dissimulait-en-realite-une-loi-anti?fbclid=IwAR1XfABp_yAn11FehSveyci4f52X4LzoXrk4EItjw XRCjyfopfCmuoHMIBI.

111 IBNOUZAHIR, Z. France. \#PasToucheAmonHijab: les femmes voilées dénoncent le projet de loi contre le séparatisme. In: Le360 [online]. 19. 4. 2021 [cit. 2021-04-22]. Dostupné na: https://fr.le360.ma/monde /france-pastoucheamonhijab-les-femmes-voilees-denoncent-le-projet-de-loi-contre-le-separatisme -237147?fbclid=IwAR3erCBNX-GYC7WmG9pB1RZfC3wE03kXoMUJwF4sGLoQbMJ6NB-361Yb $8 \mathrm{gY}$.

112 RÁDL, E. Náboženství a politika. Praha: Jan Laichter, 1921, s. 43. 
ně otevř́ít věcnou a hlavně upřímnou debatu o tom, zda jsou některá náboženství vůbec s tradičními „evropskými hodnotami“ a liberálně demokratickým státem kompatibilní, resp. zdali je rozumné ze strany státu se nestarat o náboženský život a soužití různých skupin, jak se děje v současnosti v České republice. Politika rozvolňování dozoru nad církvemi, v duchu liberálního výkladu práv ,, dejme všem církvím a náboženským společnostem naprostou volnost, smír se dostaví sám ", jde jen velmi těžko dohromady s udržením veřejného pořádku a pokojného soužití. Zvláště pak za situace, kdy jsou jednotlivá náboženství co do hodnot i organizace diametrálně odlišná. Celý problém je o to více alarmující i proto, že se děje v zemi, která nikdy tuto volnost náboženským společnostem nepřiznala, a naopak si vytvořila sofistikovaný rámec regulace jejich činnosti. Zůstává palčivou otázkou, co by se stalo, kdyby se podobný, vyhrocený hodnotový střet, vyvěrající z jiného náboženského základu, odehrával v České republice, která pro jeho řešení není, dle názoru autora, prakticky vůbec vybavená, a to jak právně, tak společensky.

\section{ZÁVĚR}

I když by se mohlo zdát, že vývoj laického státu a principu laïcité skončil ve Francii v šedesátých letech 20. století, není tomu tak. Uzavřena byla výhradně několik století dlouhá etapa boje státu s katolickou církví o moc a úpravu vzájemných vztahů. Navíc je otázkou, na jak dlouho. Dnešní zlom v otázce laicizace však nastal s masovým př́chodem obyvatel z kulturně i nábožensky odlišných prostředí, s jiným hodnotovým žebříčkem a odlišnými vzorci chování.

„Tradiční“ laický stát, který se vyvinul v reakci na mocenské ambice katolické církve a na společenskou poptávku upravit její vztah k ostatním konfesím, skončil. Soudobá společenská, politická i odborná právní debata o sekularismu ve Francii je posledních několik desítek let hnána snahou o co nejpokojnější soužití muslimské obce s většinovou částí společnosti. Pokud je nejpřiléhavější definicí laického státu ta, že se jedná o sekulární stát, který je nekonfesní a bez zásadního nebo konkordátního spojení s jedním, př́ípadně několika náboženstvími, jeho filozofický ideál je demokratický a republikánský a hodnoty liberální, je právě jeho spojení s hodnotami liberalismu a nekonfesnost v současné Francii nejvíce zpochybňováno. Je třeba i připomenout, že hlavní část výše popsaného procesu sekularizace společnosti probíhala ve spojení s demokratickým státem, ne ve vazbě na stát liberálně demokratický.

Francie má od 60. let 20. století jeden z nejkomplexnějších systémů zajištění odluky státu a církví a dohledu nad ní i ochrany široké náboženské svobody, omezené pouze veřejným pořádkem. Je založený na jednoznačně napsané ústavní úpravě a na systému provázaných zákonů, které se o ni opírají. Hlavní prim sice hraje odlukový zákon 1905, ale vše spolu vzájemně spojuje právě princip laïcité, kterému judikatura přiznává ústavní postavení. Navíc se společností, která je více jak jeden a půl století vychovávána na sekularizovaných veřejných školách k respektu k základním principům laického státu. ${ }^{113}$

${ }^{113} \mathrm{~K}$ těm patří zejména nefinancování jakéhokoliv náboženství z veřejných peněz (s výjimkami), nepodporování jakéhokoliv náboženství, sekularizované školství a tvorba zákonů oddělená od vlivu jakýchkoliv církví či náboženských společností. 
Již od 80. let 20. století se ukazuje, že staré vzorce chování, úspěšně v minulosti aplikované vůči rozpínavé katolické církvi, použity vi̊či podobně agresivnímu islámu, selhaly. A tak prrišel nejprve šátkový zákon, poté zákon zakazující zakrývání obličeje na veřejnosti a nakonec komplexní separační zákon. Je zjevné, že tím to nekončí. Vztah $\mathrm{k}$ muslimské menšině nastartoval i vnitřní změny v principu laïcité. Významněji se prosazují nové proudy jako např. laïcité identitaire, př́ípadně laïcité anti-immigrés. V rámci nich dochází k postupné vazbě laïcité na bliže nespecifikovanou formu národního katolicismu. Neschopnost francouzského státu zajistit vnější neutralitu veřejné moci, udržet náboženský život $\mathrm{v}$ soukromé sféře každého věřícího, udržet pokojné soužití mezi jednotlivými náboženskými komunitami a ateistickou společností a koneckonců i obecný veřejný pořádek má několik př́čin. $V$ prvé řadě je to odlišný hodnotový a morální normativ islámu (zejména jeho fundamentálních interpretací), který je liberálně demokratickému státu, stojícímu na hodnotách judaismu, křest'anství a osvícenského humanismu, naprosto cizí. Tento fakt by nezpůsoboval takové problémy, kdyby islám zůstal ve francouzské společnosti minoritním náboženstvím. Avšak dnes se již jedná o druhé nejpočetnější náboženství, kde počty věřících, na rozdíl od jiných náboženství, každý rok rostou.

Další problém představuje decentralizace muslimského kultu obecně. Neexistuje zde žádná jednotící síla s jasnou a nezpochybnitelnou autoritou, jakou pro katolicismus představuje papež. Islám se ve Francii shromažd’uje kolem řady kultových sdružení, prričemž každé má vlastní organizaci a financování. ${ }^{114}$ Tato roztř́íštěnost je francouzskými právními teoretiky považována za neslučitelnou se zárukou náboženské svobody a státní neutrality dle laïcité. To generuje výzvy k řádnému „zastupování“ islámu. Tyto apely vedly k tomu, že na celostátní úrovni byla v roce 2003 založena Francouzská rada muslimské víry (dále jen „CFCM“). ${ }^{115}$ Národní volený orgán sdružuje cca 25 regionálních rad muslimského kultu a má sloužit jako oficiální partner pro vyjednávání s francouzským státem, při regulaci muslimských náboženských aktivit a samozřejmě má i zastupovat všechny větve islámu ve Francii. Vytvořením CFCM se stát pokusil institucionalizovat, monitorovat a „domestikovat“ islám. Tím uzavřel deset let probíhající iniciativu, reprezentovanou sepsáním „Muslimské charty“ nebo nařízením o halal certifikaci. Vše s cílem vytvořit jakýsi „francouzský islám“."116 Nicméně, tuto organizaci nemůžeme $\mathrm{v}$ žádném případě brát tak, že je mocensky nadřazená jednotlivým imámům a kultovým sdružením, tak jak to známe např. z organizace katolické církve. Snaha francouzského státu vytvořit v rámci muslimského kultu konkrétní hierarchickou strukturu je samozřejmě logická. Francouzský laický stát a princip laïcité vznikly především v reakci na mocenské ambice katolické církve. Jenže v té měl francouzský stát vždy jasně čitelného partnera, resp. konkurenci. Nadstátně i vnitrostátně organizovaného s jednoznačně definovanou hierarchií, počínaje papežem, přes diecézní biskupy a konče jednotlivými faráři. Právě u islámu se však prokazuje, že nástroje,

${ }^{114}$ Fédération de la Grande Mosquée de Paris, Fédération Nationale des Musulmans de France, Union des Organisations Islamiques de France, Comité de Coordination des Musulmans Turcs de France, Fédération Française des Associations Islamiques d'Afrique, des Comores et des Antilles.

115 Conseil français du culte musulman.

116 MAYANTHI, F. The Republic's "Second Religion": Recognizing Islam in France. Middle East Report: Europe and Islam - the challenge of inclusion. 2005, Vol. 35, No. 235, s. 12-13. 
které má laický stát $\mathrm{k}$ dispozici, nejsou efektivně použitelné v prostředí decentralizované struktury. Za této situace proto stát není objektivně schopen vyjednat potřebný a oboustranně prijiatelný kompromis $\mathrm{v}$ agendě pokojného soužití muslimů se zbytkem společnosti. Celý spor se tak podobá „,partyzánské válce“ se státem.

Vytvořením muslimského zastupitelského orgánu se francouzský stát pokusil i o oslabení vazeb mezi muslimskými přistěhovalci a zeměmi jejich původu. Problém však představuje skutečnost, že autorita CFCM uvnitř muslimské obce je velmi malá. Proto ani zř́zení CFCM ke stabilizaci vzájemných vztahů nevedlo. Francouzský prezident Macron dal v listopadu roku 2020 CFCM ultimátum, aby představila tzv. chartu republikánských hodnot, kterou se zároveň zaváže dodržovat. Snaha souvisí s podobně formulovanou povinností pro nově zřizované sportovní federace a žadatele o dotace z veřejných zdrojů, kterou obsahuje návrh separačního zákona. Macron požaduje, aby se imámové jasně distancovali od teroristických útoků, ale také i to, aby využili svého vlivu a zabránili v působení těm z nich, kteří radikalizují věřící, sdílejí hrozby adresované křest’anské komunitě, vyzývají k teroristickým útokům nebo je schvalují. Charta má mimo jiné obsahovat i jasné odmítnutí politického islámu a jakéhokoliv zahraničního vměšování. Mimo to Macron po CFCM požaduje zřízení tzv. Národní rady imámů a odsouhlasení povinnosti, aby kazatelé museli získat oficiální akreditaci. Ta by jim byla udělena až poté, co se zavážou ke zmíněné chartě a etickému kodexu. Návrh je silně napadán jak laickou, tak i odbornou veřejností, protože je, ve své podstatě, v rozporu s výše popsanými základními principy, na kterých dosud laický stát ve Francii stál. Republika nemůže zř́́dit státem kontrolované náboženství, neměla by upravovat svůj právní řád ve prospěch nebo v neprospěch konkrétního náboženství a nemůže rozhodovat o imámech, stejně jako nerozhoduje o kněžích nebo o rabínech. ${ }^{117}$

Macron argumentuje tím, že o imámech by nerozhodoval stát, ale CFCM, resp. Národní rada imámů, a stát by situaci jen monitoroval. Jedná se tak vlastně o opačný proces, kterého jsme byli svědky ve středověku, kdy to byly naopak orgány státu, které se postupně formovaly právě pod tlakem církevní organizace. Tady jsou pod tlakem církevní struktury, které se musí přizpůsobit. Jde o jakýsi návrat k režimu galikánských (organických) článků. Autor se domnívá, že tato část požadavků prezidenta Macrona již naráží na limity „ústavního bloku“, reprezentovaného zejména čl. 1 ústavy a čl. 1 a 2 odlukového zákona 1905. Ideální by samozřejmě bylo, pokud by tato iniciativa vzešla přirozeně zevnitř samotné muslimské náboženské komunity a dostalo se jí i většinové podpory věřících, ale to je zatím zjevně nemožné.

Další problém představuje způsob financování výstavby mešit, který, jak bylo popsáno výše, stojí na penězích zahraničních dárců, zejména ze zemí, které reprezentují fundamentalistický islám. Ti se samozřejmě logicky snaží udržet si nad komunitou, soustředěnou kolem mešity, svůj vliv, a proto tam vnáší vlastní, často radikální agendu. V neposlední řadě nesmíme opomenout dlouhodobě neřešené sociální problémy, nedílně spojené s vytvářením uzavřených „ghett" na periferiích velkých francouzských měst. Ty jsou zdrojem radikálního islamismu a je zde běžně aplikován paralelní právní rád

${ }^{117}$ Macron stupňuje tlak: muslimští lídři mají do týdne předložit chartu republikánských hodnot. In: $\check{C} T 24$ [online]. 26. 11. 2020 [cit. 2021-04-25]. Dostupné na: https://ct24.ceskatelevize.cz/svet/3232252-macron -stupnuje-tlak-muslimsti-lidri-maji-do-tydne-predlozit-chartu-republikanskych. 
v podobě práva šaría. Francouzské zákony jsou zde státem prosazovány již jen omezeně a samotná „Francie“s jejími hodnotami zde již fakticky neexistuje.

Vše výše popsané vede v konečném důsledku k tomu, že se princip lä̈cité postupně bortí a s ním se rozpadá i mírové soužití jednotlivých náboženských komunit. Laïcité se ocitá v zásadním rozporu: bud' vyhovět požadavkům liberalismu, nebo udržet svou vnitřní integritu. V rámci liberálně demokratického státu dochází k zásadnímu negativnímu přehodnocování jeho hodnotových norem. Bezradnost a stále rychleji se zhoršující situace vede Francii k aplikaci nástrojů a řešení, které jdou hluboko do minulosti, prakticky až k Velké francouzské revoluci (organické články, civilní konstituce kléru, kazatelnicový paragraf, povinnost duchovního složit slib věrnosti státu). Čím dál větší důraz je kladen na potřebu ochrany veřejného pořádku, bezpečnosti a poklidného soužití (viz Prohlášení generálů ve výslužbě ${ }^{118}$ a aktivních vojáků ${ }^{119}$ ). Francie postupně zvolila dvě odlišné cesty, jak se s destabilizovaným náboženským smírem vypořádat. Nejprve se snažila přijmout náboženský pluralismus i s novými sociálními vzory a hodnotami a přizpůsobit se jim. To se ukázalo jako slepá ulička, která vedla k desekularizaci. Dnes se snaží tvrdohlavě hájit svou světskou specifičnost smíchanou, v reakci na rozmach islámu, s jakousi zatím blíže nespecifikovanou formou národního katolicismu a snahou o vytvoření národního islámu. Uvidíme, kam druhá cesta povede. Každopádně, dle názoru autora, bude vyžadovat po francouzské společnosti uzavření zcela nové společenské smlouvy.

JUDr. Petr Karola, LL.M.

Právnická fakulta Univerzity Karlovy

karola.petr@seznam.cz

\footnotetext{
118 Ze dne 21. dubna 2021.

119 Ze dne 9. května 2021.
} 